\title{
THE RELATION OF WATER TO THE BEHAVIOR OF THE POTATO BEETLE IN A DESERT
}

\author{
A DISSERTATION \\ SUBMITTED TO THE FACULTY \\ OF THE OGDEN GRADUATE SCHOOL OF SCIENCE \\ IN CANDIDACY FOR THE DEGREE OF \\ DOCTOR OF PHILOSOPHY \\ DEPARTMENT OF ZOÖLOGY
}

BY

JOSEPH KUMLER BREITENBECHER

Private Edition, Distributed By

THE UNIVERSITY OF CHICAGO LIBRARIES

CHICAGO, ILLINOIS

Reprinted from

Publication 263 of the Carnegie Institution of Washington

pp. $34 \mathrm{I}-84$ 



\title{
THE RELATION OF WATER TO THE BEHAVIOR OF THE POTATO BEETLE IN A DESERT
}

\author{
A DISSERTATION \\ SUBMITTED TO THE FACULTY \\ OF THE OGDEN GRADUATE SCHOOL OF SCIENCE \\ IN CANDIDACY FOR THE DEGREE OF \\ DOCTOR OF PHILOSOPHY \\ DEPARTMENT OF ZOÖLOGY
}

BY

JOSEPH KUMLER BREITENBECHER

Private Edition, Distributed By

THE UNIVERSITY OF CHICAGO LIBRARIES

CHICAGO, ILLINOIS

Reprinted from

Publication 263 of the Carnegie Institution of Washington pp. $34^{\mathrm{I}-}-8_{4}$ 


$$
\begin{aligned}
& 5.2945 \\
& 4684
\end{aligned}
$$




\title{
THE RELATION OF WATER TO THE BEHAVIOR OF THE POTATO BEETLE IN A DESERT
}

\author{
BY \\ J. K. BREITENBECHER \\ OF THE BIOLOGICAL LABORATORY OF WESTERN RESERVE UNIVERSITY
}

[Extracted from Publication 263 of the Carnegie Institution of Washington, pages $3+1-384$.] 


\section{CONTENTS.}

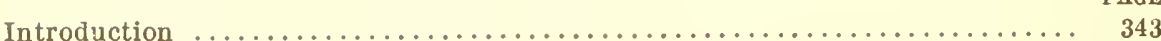

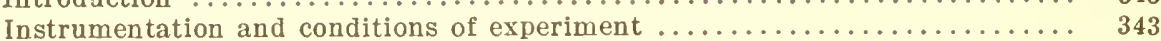

Materials . . . . . . . . . . . . . . . . . . . . . . . . . . . 344

Rôle of water in reproductive activity ....................... 346

Experiments with soil moisture ........................ 348

Experiments with evaporation rates $\ldots \ldots \ldots \ldots \ldots \ldots \ldots \ldots \ldots \ldots \ldots \ldots \ldots$

Rôle of water in the preservation of life ..................... 350

Relation of water-loss in insects when exposed to changes in the relative humidity of the surrounding medium, and its effect on the activities

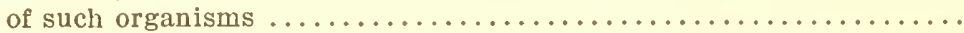

Experiments upon evaporation, transpiration, and behavior $\ldots \ldots \ldots \ldots \ldots$

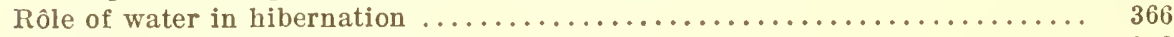

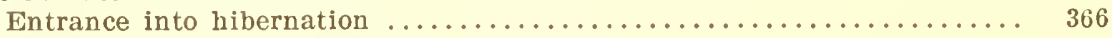

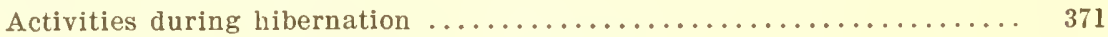

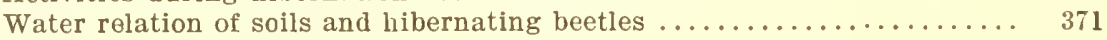

Emergence from hibernation .......................... 372

Summary and discussion upon the relation of water to hibernation ..... 373

Effect of changes in water content upon alterations in tropic activities...... 375

Experiments upon the rôle of water in geotropism ............... 376

Relation of temperature to outgo and intake of water. . . . . . . . . . . . 377

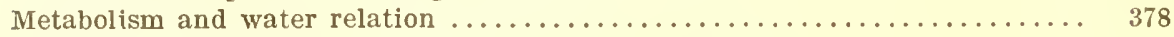

General discussion upon the rôle of water in living things . . . . . . . . . . 379

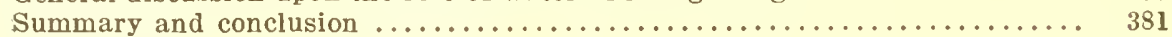

Bibliography $\ldots \ldots \ldots \ldots \ldots \ldots \ldots \ldots \ldots \ldots \ldots \ldots \ldots \ldots \ldots \ldots \ldots \ldots \ldots \ldots . \ldots \ldots$ 


\section{THE RELATION OF WATER TO THE BEHAVIOR OF THE POTATO BEETLE IN A DESERT.}

\section{INTRODUCTION.}

In a series of experiments maintained by Professor Tower to determine the action of the Tucson Desert upon evolutionary processes in chrysomelid beetles, it was observed that soil-moisture, humidity, and the like played an important rôle in modifying the activities of these organisms when introduced into the arid region; so, as a result of these observations, the author undertook a series of investigations to discover any possible connection between this water-relation and the reactions of the potato beetle, Leptinotarsa decemlineata (Say), when transplanted into the desert from a temperate habitat.

A large stock of this species was sent to Tucson from Chicago in June 1911, so that comparative studies under different environmental complexes could be made. Three cultures were established in several open-air breeding-cages at the stations already equipped for Professor Tower at Tucson and Chicago. Two of these stations, which were arid in character, are designated as Tucson Station A and Tucson Station B, while the third one, known as the Chicago Station, was temperate and located at the University of Chicago. The former of the two desert stations was situated at the base of the northern slope of Tumamoc Hill, just within the flood-plain of the Santa Cruz River, at an altitude of 2,3\%0 feet, while the latter was located on the shoulder of this hill, on which the Desert Laboratory is situated, at an elevation of 2,705 feet. The biological significance of the conditions at these stations, as indicated, is given elsewhere, and the problems dealt with concern the relations which exist between the activities of the beetles when allowed to reproduce at these localities and the changes produced in the water-content of the animals through the action of the various environmental factors.

\section{INSTRUMENTATION AND CONDITIONS OF EXPERIMENT.}

At each station the evaporation rates were obtained by the Livingston atmometers, and Friez self-recording thermographs were employed to measure the temperatures, air and soil, and the same maker's hygrographs were also uscd for the relative humidities; these instruments were calibrated and standardized fortnightly. The rainfall-readings were obtained from a standard weather bureau rain-gage at the Laboratory site. It is interesting to notice that the environmental data as recorded from these experiments showed for the arid complex that the greatest daily fluctuations occurred at Station $\mathrm{A}$ and the highest evaporation at Station B, while the lowest evaporation-rates and airtemperatures were at Station $\mathrm{C}$. The Tucson region as a whole, when contrasted with the Chicago conditions, has a higher rate of evaporation, a lower relative 
humidity, a stronger light intensity, and a wider daily fluctuation in both air and soil temperatures; excessive nocturual radiations and convectional currents were also potent factors in the desert.

Four seasons were apparent in the arid region: A winter rainy season extending from November until April; a dry fore-summer season, from April until July; a midsummer rainy season, from July until the middle of September ; and a dry after-sunmer season, from the middle of September until early in November. At Chicago rain occurred throughout the year. The amnual rainfall from several years' data was about 12 inches at Tucson and 30 at Chicago. The monthly records for both stations are given in Table 1 for the three years during which these experiments were in progress.

TABLE 1.

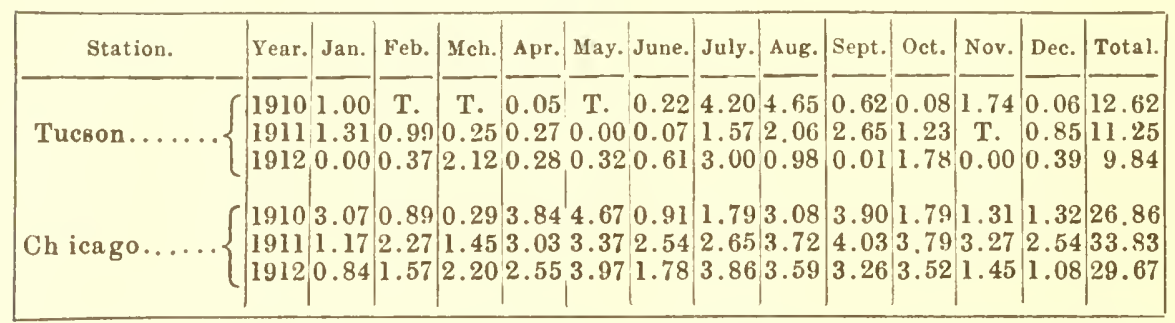

NoTE.-The rainfall records at Tucson were obtained from a standard Weather Bureau rain-gage at the Laboratory site. The Chicago data were taken from the records of the Weather Bureau.

\section{MATERIALS.}

The potato beetles were collected in May 1911, near Chicago, as they emerged from hibernation, and were allowed to breed there as a group-culture within a large cage filled with potato plants until late in June. A part of this material was then sent to Tucson, where it became the progenitor of the animals used in the majority of the experiments. Organisms when collected from nature are often hybrids, so that crossing of different generations may have taken place, but for complete breeding-records and life-histories of stocks used see Table 2, which shows that these materials reacted homozygously. A brief description of their activities follows.

At Tucson Station A these stocks were received on June 26, 1911, and immediately bred as a group-culture, so that 1,328 adults were produced in 25 days, giving generation I. After feeding upon the potato plants for a few days, these first-generation individuals were bred as a group-culture and produced generation II, numbering 2,312 progeny, in 26 days. Many of the beetles of this second generation provided the materials for a large number of the hibernation experiments which were carried on in 1911, but many of the emerged animals were allowed to hibernate during the winter of 1911-12 as stock for work during the following year. When, in June, water was added to the soil within the cage, the organisms emerged from hibernation as a group-culture, which in 29 days gave generation III, of 1,743 offspring. From this material 50 females and 50 males were mated and allowed to breed at random, giving generation IV, of 4,049 progeny, in 26 days. For the above data, see Table 2. 
At Tucson Station B the parent group of 104 adults for this culture was received on July 15 and bred as a group-culture, producing 204 offspring in 25 days, thus giving generation I. As soon as the adults from the first generation appeared they were removed to another breeding-cage, but they immediately burrowed into the ground within the experimental cages and hibernated there until September, when they began breeding and in 21 days produced generation II, of 293 progeny. A few days after emerging from pupation all of the beetles went into hibernation without feeding, where they remained until the following summer, when, on May 31, 7 males and 16 females emerged and bred immediately, giving generation III of 283 adults in 31 days. These were allowed to reproduce as a group-culture, giving in 31 days generation IV of 127 offspring.

TABLE 2.

\begin{tabular}{|c|c|c|c|c|c|}
\hline $\begin{array}{l}\text { Year, station, and } \\
\text { gcneration. }\end{array}$ & $\begin{array}{l}\text { Duration of } \\
\text { breeding. }\end{array}$ & $\begin{array}{l}\text { Period of } \\
\text { oviposition. }\end{array}$ & $\begin{array}{l}\text { First } \\
\text { stage larvie. }\end{array}$ & $\begin{array}{l}\text { Second } \\
\text { stage larva. }\end{array}$ & $\begin{array}{l}\text { Third } \\
\text { stage larva. }\end{array}$ \\
\hline 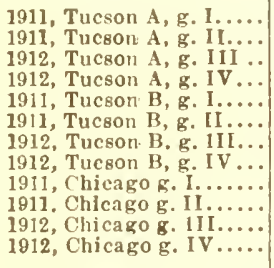 & 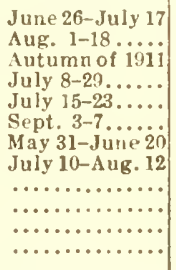 & $\begin{array}{l}\text { July } 7-19 \ldots \ldots \\
\text { Aug. 4-22 } \ldots \ldots \\
\text { June } 4-15 \ldots \ldots \\
\text { July } 15-29 \ldots \ldots \\
\text { July } 17-23 \ldots \ldots \\
\text { Sept. } 8-7 \ldots \ldots \\
\text { June } 5-20 \ldots \ldots \\
\text { July } 24-A u g .12 \\
\text { June } 6-15 \ldots \ldots \\
\text { Aug. } 1-15 \ldots \ldots \\
\text { June } 2-19 \ldots \ldots \\
\text { Aug. } 1-15 \ldots \ldots\end{array}$ & 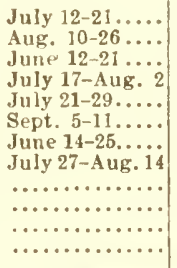 & $\begin{array}{l}\text { July } 13-27 \ldots \ldots \\
\text { Aug. } 16-31 \ldots \ldots \\
\text { June } 15-28 \ldots \ldots \\
\text { July } 20-\text { Aug. } \\
\text { July } 23-\text { Aug. } \\
\text { Sept. } 7-19 \ldots \ldots . \\
\text { June } 16-30 \ldots \ldots \\
\text { Aug. } 4-27 \ldots \ldots . \\
\ldots \ldots \ldots \ldots \ldots \\
\ldots \ldots \ldots \ldots \ldots \ldots \\
\ldots \ldots \ldots \ldots \ldots \ldots\end{array}$ & 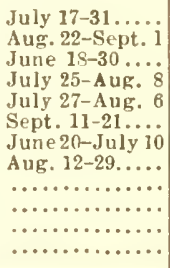 \\
\hline $\begin{array}{l}\text { Year, station, and } \\
\text { generation. }\end{array}$ & $\begin{array}{l}\text { Pupa } \\
\text { state. }\end{array}$ & $\begin{array}{l}\text { Emerged as } \\
\text { adults. }\end{array}$ & $\begin{array}{l}\text { No. of } \\
\text { adults. }\end{array}$ & $\begin{array}{c}\text { Adults } \\
\text { hibernlated. }\end{array}$ & $\begin{array}{l}\text { Duration of } \\
\text { life cycle. }\end{array}$ \\
\hline 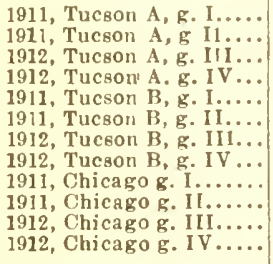 & 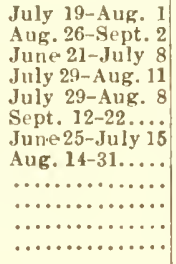 & $\begin{array}{l}\text { July } 31-A \text { ug. } 14 \\
\text { Sept. } 2-13 \ldots \ldots \\
\text { July } 4-16 \ldots \ldots \\
\text { Aug. } 8-26 \ldots \ldots \\
\text { Aug. } 10-18 \ldots \ldots \\
\text { Sept. } 19-29 \ldots \ldots \\
\text { July } 10-23 \ldots \ldots \\
\text { Sept. } 1-7 \ldots \ldots \\
\text { July } 1-20 \ldots \ldots \\
\text { Sept. } 1-10 \ldots \ldots \\
\text { July } 10-12 \ldots \ldots \\
\text { Sept. } 4-20 \ldots \ldots\end{array}$ & 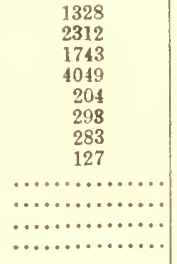 & 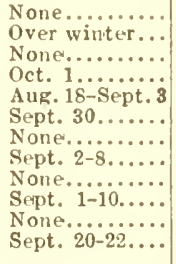 & $\begin{array}{l}25-26 \text { day } 8 . \\
22-29 \text { days. } \\
28-30 \text { days. } \\
24-28 \text { days. } \\
25-26 \text { days. } \\
20-22 \text { days. } \\
33-35 \text { days. } \\
26-36 \text { day } 8 . \\
25-36 \text { days. } \\
25-30 \text { days } \\
23-38 \text { days. } \\
34-36 \text { days. }\end{array}$ \\
\hline
\end{tabular}

Early in September all were in hibernation and remained in the ground during the winter. On the other hand, at the Chicago Station, the original wild parents were allowed to breed as a group-culture, and gave generation I in 30 days. These adults bred as a group-culture and produced generation II in 33 days, which now hibernated during the winter from September until May, when they reproduced and gave generation IV in 35 days: for the above data, see Table 2.

The animals for experiment were reared upon potato plants in cages of uniform size ( 6 by 6 by 6 feet), with sides of wire-netting, 16 meshes to the inch. These cages were furnished with wooden bottoms ( 6 by 6 by 3 feet), which were filled with a mixture of equal parts of adobe ${ }^{3}$ and sand. This mixture proved to

${ }^{1}$ At Station A, where this soil was obtained, the adobe consisted of a clay loam, which constituted the soil-mass of the river flood-plain. This soll was about 8 to 9 meters deep and rested on sand and gravel. Llvingston (1910) found it to have a water-holding power of about 18 per cent of its dry weight. The sand used in all experiments was obtained from an arroyo near at hand and liad a water-holding power of about 39 per cent of its dry weight. 
furnish favorable conditions for plant growth as well as pupation and hibernation activities.

The condition of the experiment required that a certain routine be repeated each time, and some of the most ordinary methods follow. The rates of evaporation were obtained with the Livingston atmometers, which were cut down to a cone of $50 \mathrm{~mm}$. in length to avoid an error introduced by having shellacked bases. These were standardized on the rotating machine in the Genetics Laboratory at Chicago, and showed after standardization a maximum range of 3 per cent from the normal. The dry weights of the insects were obtained as follows: first by killing them in potassium cyanide, and desiccating them at a constant temperature in a vacuum over concentrated sulphuric acid until the dry weights became approximately constant. The soil samples when collected were placed in glass-stoppered weighing-bottles and carried to the laboratory, where they were weighed and dried at a constant temperature of $100^{\circ} \mathrm{C}$. The tropic reactions were tested in the constant-temperature room $\left(18^{\circ}\right.$ to $20^{\circ} \mathrm{C}$.) and the beetles were exposed in wire-netting tubes $(30 \mathrm{~cm}$. long and $5 \mathrm{~cm}$. in diameter). All geotropic reactions were tested in the dark, and if the animals crawled to the top of the tube when held in a vertical position they were considered positive, and if they moved to the bottom of the tube, negative. The phototropic reactions were tested with an ordinary $32 \mathrm{c}$. p. electric lamp in a constant-temperature room. If the organisms crawled toward the direct rays of light when the tube was in a horizontal plane they were recorded as positive and if they moved away from the source of light as negative.

\section{RÔLE OF WATER IN THE REPRODUCTIVE ACTIVITY.}

A striking fact that one observes in desert biology is that a remarkable degree of coincidence is shown between the rainy season and the reproductive period of the animals native to such a region. Corresponding periods of inactivity for such organisms occur during the dry season. In studying this problem, Tower (1906) finds this is true for most of the species of Leptinotarsa distributed over the American deserts and similar observations were made by Semper (1881) for several desert forms.

For many years Tower has introduced chrysomelid beetles into desert complexes of Arizona from a wide range of habitats, and the majority of these experiments, which were placed under my care, showed that food, enemies, and the like were not the determining factors in the survival of such organisms, but that in most instances the survival was successful if the proper complex for the reproductive activity was attained.

Frequent observations at Tucson indicated that the optimum breeding activity of the potato beetle was coincident with the highest water-content of the medium, since periods of egg-laying were exactly concurrent with those of rain and with the low rates of evaporation. Therefore, it was important to determine experimentally what relations existed between reproductive behavior and changes of water-content within the medium surrounding these animals.

The literature of the subject contains much data in regard to the effects of temperature upon the reproductive activity, but almost none upon the relation of water to reproduction. In reference to the genus Leptinotarsa, Tower (1906) states: 
"In both tropical and temperate latitudes, the germ-cells do not develop nor reproduction take place until the conditions of temperature and moisture are favorable. . . . . Likewise, in the northern United States and Canada, decemlineata may emerge from the ground in April, but the germ-cells do not begin to grow until the coming of the warm moist days in May or possibly June."

Kammer's (190\%) experiments show that Salamandra (maculosa and atra) can be induced in varying ways to lay their eggs, depending in part upon the moisture relation. Jacobs (1909) states for the rotifer Philodina rosela:

" The period of maximum egg-production had been preceded by a period of desiccation and furthermore, that each desiccation for any length of time has been followed by an increase in the reproductive activity."

Hennings (1907), working on the bark beetle Tomicus typographus Linn., finds that the amount of water present acted as a regulatory factor for such activities. The results of these investigators show that egg-production may be modified through changed water-relations.

At Tucson Station A, comparative study of the environmental records indicated that when the atmosphere had a high water-content, and when the evaporation rates were low, then egg-laying took place most frequently. This was self-evident, for during the breeding of four generations of the stock at this locality egg-laying occurred during the following periods: July 7 to 19, August 4 to 22,1911 ; June 4 to 15 , and July 15 to 29 , 1912, which were exactly coincident with the maximum rainy periods at this station. At Tucson Station B the results were similar to those of Station A, since the periods of oviposition were as follows: July 17 to 23, September 3 to 7,1911 ; June 8 to 20 and July 24 to August 12, 1912, which coincided with high humidities and low rates of evaporation. At the Chicago station, however, the evaporation rates were lower and the egg-laying was controlled by other factors. For the desert complex these results indicated that the optimum for egg-laying was reached when the organism was subjected to a moist medium.

Since these conclusions were only probable, it was advisable that they be substantiated by further experiment. Therefore, it was necessary to produce artificial differences in the moisture-content of the medium, and observe its effect upon beetles during hibernation and after emergence.

For the purpose of these experiments, 120 beetles (Tucson A, g. II) were removed from hibernation at $8 \mathrm{p} . \mathrm{m}$. June 19 and were placed in ground-glass stoppered weighing-bottles, so that no moisture could enter. They were removed immediately to the constant-temperature room of the Desert Laboratory, where reactions were tested and all responded positively to light and negatively to gravity. At the same time a sample of the soil surrounding the beetles was taken and found to contain 11.3 per cent of water by weight. The animals were now divided into two lots of 60 adults each (30 of each sex), which were found to weigh 10.007 grams and 9.845 grams, respectively. The first batch was subjected to differences in soil-moisture and its effect upon egg-production observed. In the second case the effect of changing evaporation-rates upon oviposition was also observed. 


\section{EXPERIMENTS WITH SOIL MOISTURE.}

It was important to detcrmine the effect of a varying soil-moisture upon oviposition in these organisms during hibernation. Tubes used in experiments upon this subject were $30 \mathrm{~cm}$. long and $15 \mathrm{~cm}$. in diameter, and made of wire netting surrounded by several layers of tinfoil to prevent the egress and ingress of moisture. Three of these tubes were filled with a mixture consisting of equal parts of sand and adobe, and then sunk in a large box of sand, so that only the tops were exposed. The sand in the box was kept damp by means of selfwatering automatic soil-cups, which were devised by Hawkins (1910), the purpose of this wet sand being to keep the organisms within the tubes at a uniform temperature, a result attained through rapid evaporation of watervapor from the surface of the soil.

The desired differences in soil-moisture were produced in the above tubes in the following manner: In one tube were placed two porous soil-cups, which gave the soil a high water-content; in the second one, however, a small porous soil-cup was placed, which kept the soil within at a lower moisture than in the former; and in the third, no soil-cup was employed, thus keeping the soil dry. It was thus possible to obtain differences in soil moisture with other conditions approximately uniform. But to make certain that the above apparatus produced the desired results, determinations of soil-moisture within these tubes were made every second day throughout the experiment. These data are tabulated in Table 3, which shows that the moist soil contained 15.8 per cent moisture, the medium moist soil 8.8 per cent moisture, and the dry soil 1.9 per cent moisture. Thermometers were placed in these tubes at a depth of $15 \mathrm{~cm}$. and readings were made at 5 and $9 \mathrm{a} . \mathrm{m}$. and at 1,5 , and $9 \mathrm{p} . \mathrm{m}$. When tabulated, these soil temperatures throughout the test indicated a close agreement for all experimental tubes.

TABLE 3.

\begin{tabular}{|c|c|c|c|}
\hline Soil samples obtained. & Tube 1. Moist soil. & $\begin{array}{l}\text { Tube } 2 . \text { Medium } \\
\text { moist soil. }\end{array}$ & Tube 3. Dry soil. \\
\hline $\begin{array}{l}\text { June } 21 \ldots \ldots \ldots \ldots \\
\text { June } 23 \ldots \ldots \ldots \ldots \\
\text { June } 25 \ldots \ldots \ldots \ldots \ldots \\
\text { June } 27 \ldots \ldots \ldots \ldots \ldots\end{array}$ & $\begin{array}{c}\text { Percent. } \\
15.9 \\
15.6 \\
16.0 \\
15.8\end{array}$ & $\begin{array}{c}\text { Per cent. } \\
8.9 \\
9.2 \\
8.4 \\
8.7\end{array}$ & $\begin{array}{c}\text { Percent. } \\
1.7 \\
2.1 \\
1.8 \\
2.0\end{array}$ \\
\hline Average..... & 15.8 & 8.8 & 1.9 \\
\hline
\end{tabular}

The 60 beetles of batch 1 were now divided into three groups, and when tested in the constant-temperature chamber were found to react positively to light and negatively to gravity. Each group was now weighed, group A weighing 3.341 grams, group B, 3.329 grams, and group C, 3.337 grams, respectively. Each group was next buried on June 19 at a depth of $15 \mathrm{~cm}$. in each of the three experimental tubes as indicated, members of $\mathrm{A}$ being buried in a moist tube, those of $\mathrm{B}$ in one less moist, and those of group $\mathrm{C}$ in a dry tube. These animals remained as buried until June 27,6 p. m., when their weights were again tested in the constant-temperature room, and group A was found to weigh 3.213 grams, group B 2.962 grams, and group C 2.107 grams, respectively. 
Thus it was discovered that the beetles of group A from the moist soil showed a loss of only 0.128 gram, while their reactions were, as before, positive to light and negative to gravity. The beetles of group B, however, from the medium moist soil, showed a much greater loss in weight $(0.367$ gram), although their responses were unchanged, except in the case of 3 which were positive to gravity. The beetles of group $\mathrm{C}$ from the dry soil indicated the greatest decrease in weight (1.123 grams), and showed a reversal in their behavior.

After this test the beetles were put into separate cages out-of-doors and allowed to breed under natural conditions. A comparison of the rates of evaporation, obtained with Livingston atmometers when placed within these cages, indicated that the environment was uniform. When the activities of these insects were closely observed, the following results were obtained: Those beetles from the wet soil, whose reactions as previously tested, were still positive to light and negative to gravity, moved immediately upward on the potato plants, and began feeding on the uppermost leaves. This indicated that their activities were normal, and on June $30 \mathrm{eggs}$ were laid. On the other hand, those animals from the medium-wet soil also fed on these plants, but no eggs were laid until July 4 . This showed that oviposition was postponed 4 days, but that the dry-soil beetles, whose responses were now reversed, were negative to light and positive to gravity. They immediately burrowed into the ground and remained there until the arrival of the summer rains, July 13, when they emerged and laid eggs on July 15. In this case oviposition was delayed 15 days. An analysis of these results follows:

These experiments showed that differences in soil-moisture produced changes in the water-content of these animals as well as modified their behavior. Since the egg-production was changed, we must conclude that beetles emerging from soils of high moisture-content lay their eggs sooner than those issuing from drv soils. The soil no doubt has played an important rôle in the economy of desert organisms, which are known to respond accurately to environmental changes such as we have described; otherwise many forms would have ceased to exist where they are now widely distributed in desert regions.

\section{EXPERIMENTS WITH EVAPORATION RATES.}

The second batch of beetles was used to determine the effect of differences in rates of evaporation upon insects just emerged from hibernation. The apparatus for this experiment consisted of three uniform bell-jars placed over pots of potato plants. Each pot was sunk into adobe soil in the bottom of a vivarium, which was an open inclosure covered with wire netting. One of the bell-jars was provided with 8 atmometers, which, through the evaporation of water-vapor from their surfaces, produced both a high relative humidity and a low rate of evaporation. The second jar was furnished with 2 atmometers, and the evaporation-rate was greater in this jar than in the first; but the third was kept dry, for, since no water or atmometer whatsoever was used, a high rate of evaporation was secured. The food-plants in this test were kept in a normal healthy condition by the use of automatic soil-watering cups placed in the earth near the bottom of the pots. A few preliminary experiments demonstrated that the dry bell-jar in direct sunshine would become several degrees warmer than the more moist; consequently a shade was so placed as to give 
closer agreement in temperature readings. A small strip of wire-netting was then fastened around the base of each bell-jar to afford a free circulation of air.

The environmental conditions produced artificially within each bell-jar were measured in the following manner: Thermometers were suspended in each jar and temperature readings were taken five times daily at 5 and 9 a.m., 1, 5, and 9 p. m.; they show a close agreement of the three jars. The evaporation-rate was obtained by means of a single atmometer placed in each jar, and the cubic centimeters evaporated by this instrument were recorded twice each day at $8 \mathrm{a} . \mathrm{m}$. and $8 \mathrm{p.m}$. In averaging the different rates, it was found that the moist jar showed an evaporation rate of 14.5 c. c. daily, the medium moist 20.7 c. c., and the dry 25.0 c.c., respectively. The results show that the air temperatures within each jar were approximately uniform during progress of the experiment, and furthermore that the anticipated differences in the rates of evaporation were produced in this manner. Thus the environmental conditions for this test were experimentally attained.

Sixty beetles of batch 2 were now divided into three groups of 20 each, and on June 20 were distributed to the jars mentioned above. In the jar with a low rate of evaporation the beetles reacted normally in feeding upon the potato plants, and laid eggs on the third day, June 23, but in the jar with the medium evaporation-rate, the animals, though resting upon the plant leaves, laid no eggs for 9 days, or until June 29. In the third jar, with a high rate of evaporation, which produced the greatest degree of desiccation, they stayed upon the potato vines for 5 days or until June 25, when they entered the ground and there remained until the summer rains began July 11 ; they emerged, however, from the soil on July 13, and oviposition occurred within 3 days.

These results showed that egg-production was modified by differences in the evaporating power of the air surrounding these animals, and that a low rate of evaporation, coincident with a high water-content, encouraged oviposition, but that a high rate of evaporation, which reduced their water-content, retarded reproduction. So with a high rate of evaporation the beetles were desiccated; their tropisms were reversed and they entered the soil, where they remained until their moisture-content was sufficiently increased; they absorbed water until their reactions became normal, when emergence resulted.

It was shown clearly that reproductive activity occurred during a period of high water-content in the surrounding medium, whether atmosphere or soil, and that desiccation, by reversing the animal's tropisms, inhibited and postponed reproductive reactions of the $L$. decemlineata, which is a typical grassland organism. This demonstrated that the introduced stock had adjusted itself to the complex of desert conditions and reacted in the same manner as did the indigenous organisms of the surrounding region. Accordingly, in the majority of species, we should expect reproduction to coincide with the season of high water-content and a dormant period to follow the dry season, regardless of any discovered structural adaptations.

\section{RÔLE OF WATER IN THE PRESERVATION OF LIFE.}

In the desert it was found that hibernating insects could continue life during long dry seasons of one or more years; therefore, experiments were undertaken to answer the following questions: How was such vitality preserved? Was this 
relation due to a reduction of normal physiological activities through desiccation? If so, what relation exists between such organisms and changes in the physical composition and especially the moisture-content of the medium surrounding them? For these tests, animals of different physiological activities, induced by differences in humidity, were buried for certain periods of time in soils of varying degrees of moisture and texture. The criteria used in determining the power of resistance were the number of individuals surviving in the test at the end of a given period of time, and the differences in activities of the insects produced through desiccation, as compared to a similar set in which the behavior was normal. The capacity of these animals to resist was tested, and beetles were placed in wire-netting tubes $(50 \mathrm{~cm}$. long by $10 \mathrm{~cm}$. in diameter) which permitted a free circulation of air and moisture. The tubes containing the insects wero buried upright, so that the base of each was $60 \mathrm{~cm}$. deep in the soil. The plots were 10 meters apart, in the open, at Tucson Station A. Earth was removed from each plot so as to leave two holes 6 meters square by 1 meter deep, and each cavity was further divided into equal parts by a partition of red-wood boards 1 inch thick; one side was filled in with sand, the other with adobe. One of these plots was exposed under natural conditions in the open, while the other was covered with a roof, which extended on each side 1 meter beyond the limits of the plot. This roof was raised 1.5 meters above the ground in order to give a free circulation of air and to keep the soil dry underneath. Water from rains was collected in ditches which conveyed it beyond the plot. The plot in the open was designated Plot $A$, and that under roof as Plot B. The soils in both plots were kept moist by adding water by means of a garden hose until October 20, but after this date they were exposed to the conditions of the winter of 1911-12 at Tucson.

The first set of experiments concerned only beetles of the summer generation that were emerging from the pupa state. Such insects do not normally hibernate, but may be caused to do so through adverse conditions such as those which cause desiccation. It should be noticed that in one instance the animals were buried with all activities normal; in the other, they were first induced to hibernate in cages in the vivarium, and they were sifted out in the soil; in either case they were finally buried under the conditions described above.

In the former test in which the beetles were buried with all their activities normal, 400 emerging individuals (Tucson A, g. I) were collected on August $12 ; 50$ of these were then placed into each of the 8 wire-netting tubes; 4 of these tubes were filled with sand and 4 with adobe soil; the insects were placed at corresponding levels in each of the 8 tubes; 2 of these containing sand were buried in the open plot and 2 under the shelter, while the 4 tubes with adobe soil were sunk in the adobe sections of the plots, 2 in each. These were left unmolested until May 1, when one tube under each set of conditions was examined but no living beetles were found. On October 1 , the remaining 4 tubes were inspected with the same results; there were no living organisms found. These results showed that no beetles of the summer generation with their activities normal hibernated successfully when buried under the conditions of this experiment. These observations are tabulated in Table 4. 
In the latter test, however, the insects were first induced to hibernate in cages in the vivarium, and were then immediately sifted out of the soil, to be finally buried in Plots A and B. The following methods were used in this test: During the period of August 13 to 20, emerging adults to the number of 1,613 (Tucson A, g. I) were collected and placed in pedigree cages under adverse conditions within the vivarium. These conditions were produced by having their food reduced to sliced potato tubers and by adding just enough water to keep the soil slightly moist, so that the beetles were partially desiccated. A census taken September 10 showed that 1,209 insects had successfully hibernated in

TABLE 4.-Census of counts on covered plot and open plot.

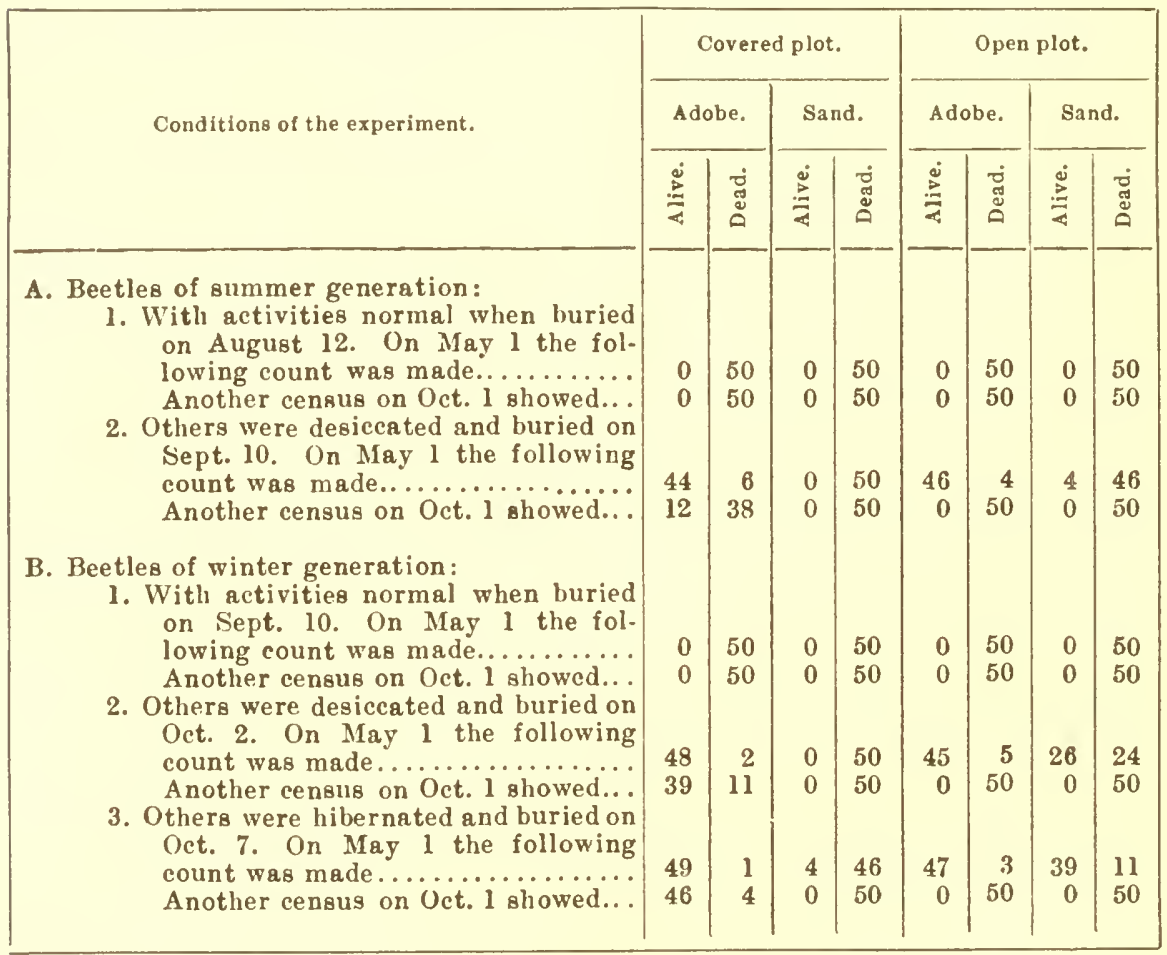

these cages, and from this result, it was discovered that their vitality was greatly diminished, for 67 per cent of them were killed by these conditions. Of the survivors, 400 were divided into 8 groups of 50 individuals each, which were placed in tubes buried beside the 8 which were described in the former test. All were left unmolested during the winter and until May 1, when 4 tubes from each plot were examined. Tubes from the covered plot showed that those in sand contained no life; 2 from adobe contained 54 living beetles; while 4 were alive in the sand from the covered plot; the adobe portion of this harbored 46 living insects. On October 1 the remaining 4 tubes were also examined; those in adobe soil under shelter contained 12 living beetles, but all were dead in the sand and there were no living animals in either part of the open plot. These experiments proved that beetles of the summer generation, which normally 
breed and produce a hibernating winter generation, may be buried after having been induced to enter the ground through desiccation; furthermore, that the animals lived many months when buried under these conditions, but that the death-rate was greater in the sand, and the majority in the open plot succumbed. These data are also given in Table 4.

On the other hand, the second set of experiments concerned beetles of the winter generation which had just emerged from the pupa state. This problem was considered from three aspects: (1) Some animals were buried with all their activities normal; (2) others were induced to hibernate through partial desiccation produced through adverse conditions, and were then buried; (3) many were allowed to hibernate normally before they were finally buried in the two plots.

For the first test in which the animals were buried with all their activities normal, 400 emerging adults (Tucson A, g. II) were collected on September 10; they were placed within the sand and adobe portions of the two plots. During the winter, and until May 1, they were left unmolested, when tubes from each plot were examined and no living individuals were discovered. On October 1 the remaining tubes were exhumed, but no live animals were found. These results showed that, when beetles of the winter generation, which normally . hibernate, were buried with all their activities normal, hibernation was unsuccessful and all the animals succumbed (Table 4).

In the second test, where beetles were induced to hibernate through desiccation, 1,000 emerging adults (Tucson A, g. II) were collected on September 11, and were placed under adverse conditions in pedigree cages in the vivarium, where their food was sliced potato, as in a previous test. On October 2, hibernating adults to the number of 692 were sifted from the soil, and 308 dead ones were gathered from its surface; 400 of the living insects were then divided into 8 groups, and were buried within the soils of the two plots, in order to afford the opportunity of winter hibernation. On May 1 these tubes were examined for living beetles; the tube from sand under the covered plot contained no living adults, while in the one from adobe earth were found 48 living adults; also those in sand from the open plot contained only 26 living individuals, while 45 beetles were removed from the tubes in adobe. In a similar manner, on October 1 , the remaining 4 tubes were removed. In the adobe soil tube, under the shelter, were found 39 animals, but no individuals hibernated successfully in sand; moreover, tubes from the open plot harbored no life. The results indicate that induced hibernation was effected in the winter generation through desiccation, which increased the resistance of these animals by decreasing their normal activities. The only insects alive at the end of the experiment were found in adobe under the corered plot, which proved that potato beetles, when hibernating in adobe, possessed a greater resistance to desiccation than when buried in sand (Table 4).

In the last test, insects were permitted to hibernate normally, then buried in Plots A and B. This was a control for former tests, since it showed that no error was introduced through handling or digging up the animals. For this test, 1,000 emerging adults (Tucson A, g. II) were collected on September 13; they were placed in a large out-of-door cage that was provided with potato plants, and other envirommental conditions were apparently normal. After consuming much food, these animals were in hibernation by October $\%$; then, 
400 of these were sifted from the soil and buried in the adobe and sand portions of the two plots, after having been placed in tubes as in previous tests. On May 1, when 4 tubes from these plots were examined, it was found that the tube from adobe in the covered shelter showed 49 living beetles, while the one from sand contained only 4 ; on the other hand, the tube from the adobe portion of the open plot was found to have 47 living insects, and those from sand 39 . On October 1, when the remaining 4 tubes were removed, those in adobe from the sheltered plot contained 46 live animals, but those in the sand none; those from the open plot contained no individuals which had hibernated successfully. This natural type exhibited the greatest resistance because of the large number of survivals, and it also appeared that adobe was more favorable to the maintenance of life than was sand.

In Table 4 the results are briefly indicated; it is shown there that insects with all activities normal die when buried, for no beetles were found under any of these conditions. It appears also that either the summer or winter generation may be buried and still live, providing the animals were desiccated previous to burial. It is also shown that a covered plot with adobe soil is a most favorable condition for the preservation of life. It is also demonstrated that insects can be desiccated at any time, when they will burrow into the ground, and may remain there many months without apparent injury. These tests further show that the large pores in sand permitted too rapid drying, so that the animals were desiccated beyond recovery. Livingston (1910) shows that this adobe soil has a water-holding power twice as great as sand, which agrees with the above results and explains why these insects continued to live. Lastly, since the adobe soil in an arid region does contain such a high percentage of moisture, it therefore is the best medium for the sustentation of desert life.

\section{RELATION OF WATER LOSS IN INSECTS WHEN EXPOSED TO CHANGES IN THE RELATIVE HUMIDITY OF THE SUR- ROUNDING MEDIUM AND ITS EFFECT ON THE ACTIVITIES OF SUCH ORGANISMS.}

The relation of water-loss, $i$. e., transpiration and respiration from exposed surfaces, to the behavior of plants and animals has already received some attention. This is especially true of plants, the water-relations of which have been studied by Livingston (1906), Lloyd (1912), MacDougal (1912), Renner $(1910,1911)$, and other plant physiologists. The results of Livingston (1906) are of interest in this connection, since they show that there is a close relation between the daily march of evaporation, as measured by the atmometer, and transpiration in plants. The following experiments upon insects show that these animals exhibit a physiological behavior not unlike that of transpiration in plants, but the results further show that tropisms of insects are modified by loss of water, which in turn is governed by the evaporating power of the air. There is wide literature upon perspiration, but it does not bear directly upon our problem; accordingly we shall consider such researches as have been made upon transpiration and evaporation and the efficiency of these processes in modifying behavior.

The results which follow upon the behavior of insects and other desert animals and upon the relation of evaporation to their behavior and life economy was 
reported, by the present writer $(1911,1912)$, and these results have been substantiated by Shelford $(1914 a, b)$ and his students, Weese (1917), Hamilton (1917), and Chenoweth (1917). The writer's experiments upon the potato beetle and other desert animals (1911) showed that "the fundamental activities of this beetle, as well as those of many desert organisms, are directly conditioned by their water-content or water-balance. The water-content of the beetle is determined by the evaporating capacity of the air, the leaf-moisture content of its food plant, soil-moisture, and temperature. Variation in any one of these factors may influence not only hibernation, but other habits and reactions." This work was carried on during the next year (1912), in which I stated regarding the behavior of desert animals that "the proportion of water held in the body, or the water-balance, is correlated with various activities, and the lowering of this balance, or surplus, inhibits several functions or processes, and is also followed by reversed response to various external agencies which may exert a stimulatory action."

Shelford (1913) records that certain spiders, ground-beetles, wasps, millipeds, frogs, and salamanders react in consequence of evaporation, and that a short exposure to evaporation conditions increases sensibility to it. Aside from this experimental data, Shelford and Deere (1913) established laboratory methods for determining the reactions of the above animals to evaporation gradients. My experiments differ from Shelford's in being made under natural conditions out-of-doors, while his studies were undertaken in the laboratory.

Hamilton (1917) studied certain soil insects, in the full-grown larval and adult state, of the family Carabidx, and his results tended to show that an increase in the rate of air-flow did not effect the larvæ as much as did an increase in temperature or a decrease in relative humidity; the adults, moreover, offered greater resistance to evaporation and temperature. The experiments upon the horned lizard by Weese (1917) demonstrated a clear-cut reaction to the substratum temperature gradient, while the evaporation gradient was not the limiting factor. On the other hand, Chenoweth (1917) concludes that the evaporating power of the air is the best index of environmental conditions affecting the white-footed woodland mouse, as well as other land mammals, and that the mice reacted to evaporation whether it was produced by movement, dryness, or heat.

\section{EXPERIMENTS UPON EVAPORATION, TRANSPIRATION, AND BEHAVIOR.}

Previous experiments upon $L$. decemlineata show that tropic activities for light and gravity can be reversed through desiccation, and furthermore, that normal reactions are restored if the bectles were surrounded by a moist medium. On the other hand, it seemed important in this connection to perform certain experiments, in order to determine if these insects in nature react to losses of water, which might be produced through desiccation by means of the evaporating power of the air immediately surrounding them. Therefore, it seemed advisable to devise certain tests which would show the daily march of evaporation and transpiration when compared with their behavior.

The first experiment was made to determine the relation between the daily progress of evaporation and transpiration rates of $L$. decemlineata when exposed at three different strata, which were produced by an association of potato plants that completely filled the bottom of a cage, 6 feet square by 4 feet high, and 
covered with wire-netting. This dense growth produced horizontal zones with atmospherical moisture, varying from high water-content at the bottom of the cage to one of low content above the plants in the open.

All beetle exposures and environmental measurements were made every 2 hours for a period of 12 observations at 3 strata within the cage, where insects and instruments were exposed within wire-netting tubes, $30 \mathrm{~cm}$. long and $5 \mathrm{~cm}$. in diameter. Stratum A was $5 \mathrm{~cm}$. above the ground near the base of the potato plants, and contained the greatest moisture, thus giving the lowest evaporation rate; stratum B was $60 \mathrm{~cm}$. above the ground, near the center of the cage among the plants, and was directly above stratum A, so that it contained less moisture, which gave a medium rate of evaporation; while stratum $\mathrm{C}$ was $90 \mathrm{~cm}$. above ground and $5 \mathrm{~cm}$. above the tops of the plants, and furnished the driest conditions, with a high evaporation-rate, which was the only exposure to true desert conditions. Each stratum was directly above the other, and all exposures were made near the center of the cage. The environmental measurements were obtained as follows: The evaporation rates, by using Livingston atmometers; relative humidities from wet and dry bulb readings; temperatures, from uniform standard centigrade thermometers.

The environmental measurements were made every 2 hours for a period of 12 observations at the 3 strata within the experimental cage as previously described and at the beginning of each period a new batch of beetles was exposed to these conditions for 2 hours. The results are given in table 5 .

The beetles used in this experiment (Tucson A, g. II) were collected as soon as possible after their emergence. Since these newly emerged individuals take no food until after 24 hours, all collections were made previous to this time, so that no error might be introduced in consequence of feeding; moreover, no food was given them at any time, and no excretion of waste products by the animals was observed throughout the test. The beetles were placed at once in bell-jars of uniform size in the constant-temperature room, which stood at $24^{\circ} \mathrm{C}$., and a high but uniform relative humidity was produced by placing wet filter-paper inside the jars; this kept the air of the jars approximately saturated and the beetles absorbed moisture until their reactions and physiological states were uniform, as was proved by tests made later.

The animals were retained in the jars until needed for further experiment. Three batches of 10 beetles were removed from the constant-temperature room, and exposed every 2 hours in wire-netting tubes, at the 3 strata within the cage. Each batch was made up of similar stocks as follows: 4 individuals of 180 adults which had emerged on July 5 were placed in the constant-temperature room at 8 a. m. July $6 ; 3$ adults of 110 individuals which had emerged on July 6 were also placed in this chamber on July 7 ; and 3 animals of 124 adults which had emerged on July 7 were likewise placed in this room at 10 a. m. July 8 ; while a batch of 30 beetles which emerged July 8 received the same treatment at $12 \mathrm{p} . \mathrm{m}$. July 8 , and were used during the last 2 hours of the experiment, beginning at 4 p. m. on July 10. Thus all the organisms used were of the same culture and of the same parents; in general they were of the same age, and approximately of similar states, so the conditions of the test were uniform.

Aside from the environmental records, the following was also determined as far as the insects were concerned: the total weight in grams of 10 beetles when exposed, their weight in grams after 2 hours' exposure, the total grams of dry 
weight for each batch exposed, the grams of water in the beetles, the total percentage of water in the animals, the loss percentage of water in terms of entire weight, and the loss percentage of water in terms of dry weight (Table 5).

TABLE 5.

\begin{tabular}{|c|c|c|c|c|c|c|c|c|c|c|c|c|}
\hline 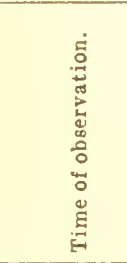 & 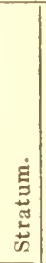 & 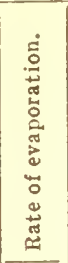 & 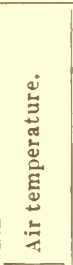 & 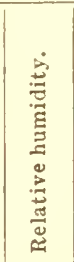 & 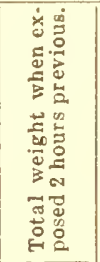 & 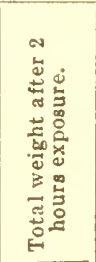 & 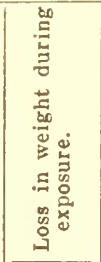 & 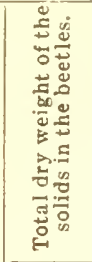 & 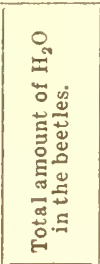 & 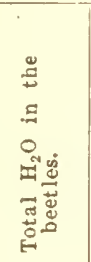 & 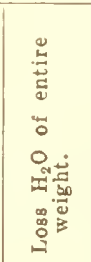 & 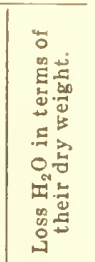 \\
\hline & B & $\begin{array}{cc}c . & c . \\
2.0 \\
2.3 \\
3.6\end{array} \mid$ & $\begin{array}{l}\cdot C . \\
26.8 \\
26.8 \\
27.3\end{array}$ & $\begin{array}{c}\text { p. } c t \text {. } \\
36 \\
33 \\
30\end{array}$ & $\begin{array}{c}\text { gms. } \\
1.2957 \\
1.2879 \\
1.2367\end{array}$ & $\begin{array}{c}g m s . \\
1.2700 \\
1.2574 \\
1.2028\end{array}$ & $\begin{array}{c}g m s . \\
0.0257 \\
0.0305 \\
0.0339\end{array}$ & $\begin{array}{c}\text { gms. } \\
0.239 \\
0.235 \\
0.229\end{array}$ & $\begin{array}{c}g m s . \\
1.0567 \\
1.0529 \\
1.0077\end{array}$ & $\begin{array}{l}\text { p. ct. } \\
81.55 \\
81.75 \\
81.48\end{array}$ & $\begin{array}{l}p . c t . \\
2.43 \\
2.89 \\
3.36\end{array}$ & $\begin{array}{l}\text { p.ct. } \\
10.75 \\
12.98 \\
14.80\end{array}$ \\
\hline 1 & $D$ & $\begin{array}{l}2.2 \\
3.3 \\
6.0\end{array}$ & $\begin{array}{l}27.9 \\
33.2 \\
33.9\end{array}$ & $\begin{array}{l}35 \\
23 \\
22\end{array}$ & $\begin{array}{l}1.2435 \\
1.2860 \\
1.2400\end{array}$ & $\begin{array}{l}1.2150 \\
1.2405 \\
1.1585\end{array}$ & $\begin{array}{l}0.0285 \\
0.0455 \\
0.0815\end{array}$ & $\begin{array}{l}0.230 \\
0.275 \\
0.226\end{array}$ & & $\begin{array}{l}81.50 \\
78.42 \\
81.73\end{array}$ & $\begin{array}{l}2.81 \\
4.50 \\
8.04\end{array}$ & $\begin{array}{l}12.40 \\
16.51 \\
35.98\end{array}$ \\
\hline & 1 & $\begin{array}{l}2.7 \\
4.6 \\
9.5\end{array}$ & \begin{tabular}{|l|}
30.8 \\
36.2 \\
36.2
\end{tabular} & $\begin{array}{l}35 \\
19 \\
15\end{array}$ & $\begin{array}{l}1.1840 \\
1.1740 \\
1.1870\end{array}$ & & & $\begin{array}{l}0.223 \\
0.213 \\
0.218\end{array}$ & & $\begin{array}{l}81.16 \\
81.85 \\
81.63\end{array}$ & $\begin{array}{r}3.58 \\
5.66 \\
14.14\end{array}$ & $\begin{array}{l}10.42 \\
25.53 \\
62.84\end{array}$ \\
\hline & 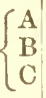 & $\begin{array}{r}4.3 \\
8.4 \\
17.6\end{array}$ & $\begin{array}{l}33.3 \\
40.2 \\
40.0\end{array}$ & $\begin{array}{l}30 \\
15 \\
12\end{array}$ & $\begin{array}{l}1.2090 \\
1.2750 \\
1.2140\end{array}$ & & $\begin{array}{l}0.0770 \\
0.1160 \\
0.1735\end{array}$ & $\begin{array}{l}0.232 \\
0.272 \\
0.236\end{array}$ & & & $\begin{array}{r}7.88 \\
11.56 \\
17.74\end{array}$ & $\begin{array}{l}33.19 \\
42.64 \\
73.51\end{array}$ \\
\hline & 3 & $\begin{array}{r}4.6 \\
8.9 \\
19.4\end{array}$ & $\begin{array}{l}33.9 \\
40.5 \\
40.0\end{array}$ & $\begin{array}{l}28 \\
13 \\
11\end{array}$ & $\begin{array}{l}1.2415 \\
1.1005 \\
1.2540\end{array}$ & & $\begin{array}{l}0.0800 \\
0.1200 \\
0.2740\end{array}$ & $\begin{array}{l}0.229 \\
0.209 \\
0.232\end{array}$ & & $\begin{array}{l}81.55 \\
81.00 \\
81.46\end{array}$ & $\begin{array}{r}7.90 \\
13.46 \\
26.82\end{array}$ & $\begin{array}{r}34.93 \\
57.41 \\
117.84\end{array}$ \\
\hline & B & $\begin{array}{r}5.3 \\
8.1 \\
16.1\end{array}$ & $\begin{array}{l}28.3 \\
37.3 \\
37.1\end{array}$ & $\begin{array}{l}33 \\
15 \\
12\end{array}$ & $\begin{array}{l}1.2565 \\
1.2230 \\
1.1965\end{array}$ & $\begin{array}{l}1.2015 \\
1.1185 \\
1.0550\end{array}$ & $\begin{array}{l}0.0550 \\
0.1045 \\
0.1415\end{array}$ & $\begin{array}{l}0.215 \\
0.213 \\
0.217\end{array}$ & & $\begin{array}{l}82.73 \\
82.58 \\
81.86\end{array}$ & $\begin{array}{r}5.28 \\
10.34 \\
14.44\end{array}$ & $\begin{array}{l}25.57 \\
49.06 \\
65.20\end{array}$ \\
\hline & $B$ & $\begin{array}{r}4.6 \\
7.6 \\
14.3\end{array}$ & $\begin{array}{l}28.4 \\
34.0 \\
33.4\end{array}$ & $\begin{array}{l}35 \\
19 \\
14\end{array}$ & & $\begin{array}{l}1.1815 \\
1.1885 \\
1.2110\end{array}$ & & $\begin{array}{l}0.210 \\
0.219 \\
0.234\end{array}$ & & & $\begin{array}{l}2.16 \\
4.85 \\
6.41\end{array}$ & $\begin{array}{l}10.24 \\
22.60 \\
28.63\end{array}$ \\
\hline 10 & C & $\begin{array}{l}3.0 \\
4.6 \\
9.0\end{array}$ & $\begin{array}{l}25.4 \\
30.6 \\
30.0\end{array}$ & $\begin{array}{l}43 \\
24 \\
17\end{array}$ & $\begin{array}{l}1.2080 \\
1.1580 \\
1.2565\end{array}$ & $\begin{array}{l}1.1845 \\
1.1295 \\
1.2160\end{array}$ & $\begin{array}{l}0.0235 \\
0.0285 \\
0.0405\end{array}$ & $\begin{array}{l}0.213 \\
0.214 \\
0.239\end{array}$ & & $\begin{array}{l}81.47 \\
80.97\end{array}$ & $\begin{array}{l}2.36 \\
3.02 \\
3.98\end{array}$ & $\begin{array}{l}11.00 \\
13.28 \\
16.95\end{array}$ \\
\hline 12 & B & $\begin{array}{l}2.0 \\
3.1 \\
6.9\end{array}$ & $\begin{array}{l}25.0 \\
29.7 \\
29.0\end{array}$ & $\begin{array}{l}44 \\
27 \\
23\end{array}$ & & $\begin{array}{l}1.2375 \\
1.1900 \\
1.1606\end{array}$ & & $\begin{array}{l}0.228 \\
0.223 \\
0.220\end{array}$ & & $\begin{array}{l}81.99 \\
81.76 \\
81.75\end{array}$ & $\begin{array}{l}2.74 \\
3.30 \\
4.55\end{array}$ & $\begin{array}{l}14.79 \\
20.40\end{array}$ \\
\hline 2 & B & $\begin{array}{l}2.1 \\
3.2 \\
6.7\end{array}$ & $\begin{array}{l}24.1 \\
28.0 \\
27.5\end{array}$ & $\begin{array}{l}47 \\
31 \\
27\end{array}$ & $\begin{array}{l}1.1727 \\
1.1693 \\
1.1384\end{array}$ & $\begin{array}{l}1.1420 \\
1.1380 \\
1.0489\end{array}$ & $\begin{array}{l}0.0307 \\
0.0313 \\
0.0489\end{array}$ & $\begin{array}{l}0.224 \\
0.222 \\
0.213\end{array}$ & & $\begin{array}{l}80.01 \\
81.29\end{array}$ & $\begin{array}{l}3.23 \\
3.30 \\
5.28\end{array}$ & $\begin{array}{l}14.09 \\
22.91\end{array}$ \\
\hline 4 & B & $\begin{array}{l}1.3 \\
3.1 \\
5.1\end{array}$ & $\begin{array}{l}24.3 \\
27.1 \\
27.2\end{array}$ & $\begin{array}{l}45 \\
28 \\
25\end{array}$ & $\begin{array}{l}1.1422 \\
1.2815 \\
1.1390\end{array}$ & $\begin{array}{l}1.1122 \\
1.2435 \\
1.0990\end{array}$ & $\begin{array}{l}0.0300 \\
0.0380 \\
0.0400\end{array}$ & $\begin{array}{l}0.224 \\
0.251 \\
0.225\end{array}$ & $\begin{array}{l}0.9182 \\
1.0305 \\
0.9140\end{array}$ & $\begin{array}{l}80.40 \\
80.25\end{array}$ & $\begin{array}{l}3.26 \\
3.68 \\
4.37\end{array}$ & $\begin{array}{l}15.13 \\
17.77\end{array}$ \\
\hline 6 & $\left\{\begin{array}{l}\mathrm{A} \\
\mathrm{B} \\
\mathrm{C}\end{array}\right.$ & $\begin{array}{l}1.2 \\
3.1 \\
4.9\end{array}$ & $\begin{array}{l}22.3 \\
25.2 \\
25.2\end{array}$ & $\begin{array}{l}56 \\
33 \\
27\end{array}$ & $\begin{array}{l}1.4385 \\
1.4550 \\
1.5375\end{array}$ & $\begin{array}{l}1.3975 \\
1.4010 \\
1.4795\end{array}$ & $\begin{array}{l}0.0410 \\
0.0540 \\
0.0580\end{array}$ & $\begin{array}{l}0.301 \\
0.312 \\
0.328\end{array}$ & $\begin{array}{l}1.1375 \\
1.1430 \\
1.2095\end{array}$ & $\begin{array}{l}79.07 \\
78.56 \\
78.66\end{array}$ & $\begin{array}{l}3.60 \\
4.72 \\
4.79\end{array}$ & $\begin{array}{l}17.30 \\
17.68\end{array}$ \\
\hline
\end{tabular}




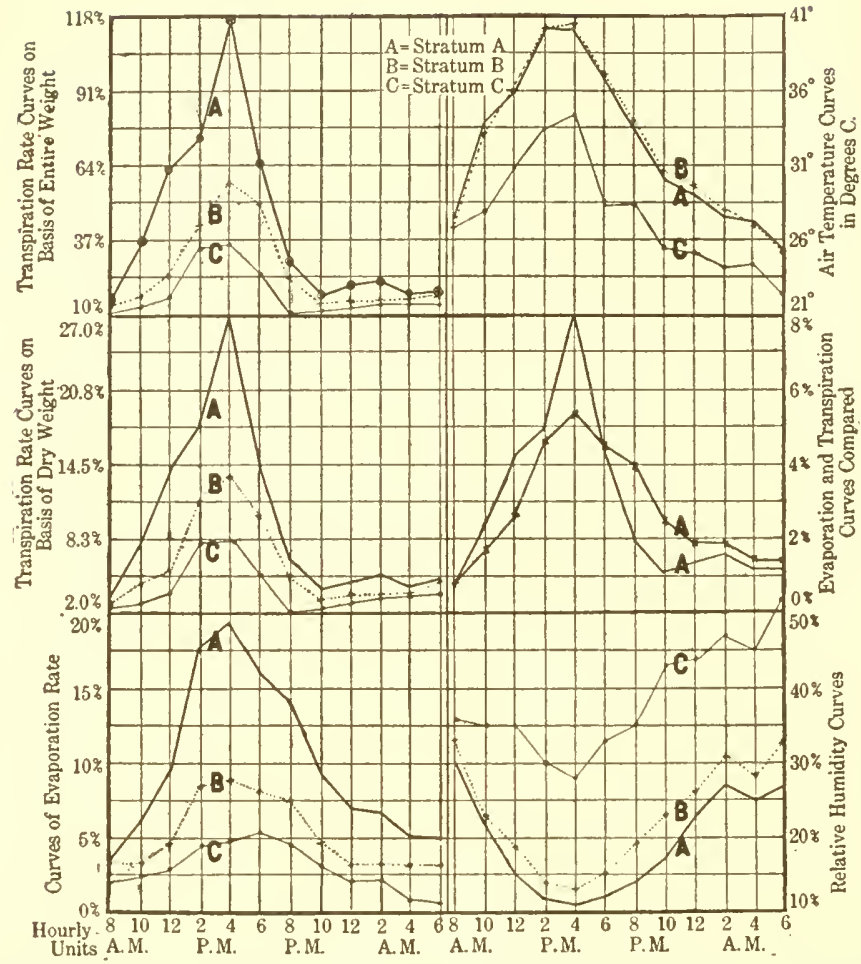

Fig. 1.-Curves showing relation between dally progress of evaporation and trauspiration rates of beetles when exposed to different strata produced by an association of potato plants. Consult table 5 for above data.

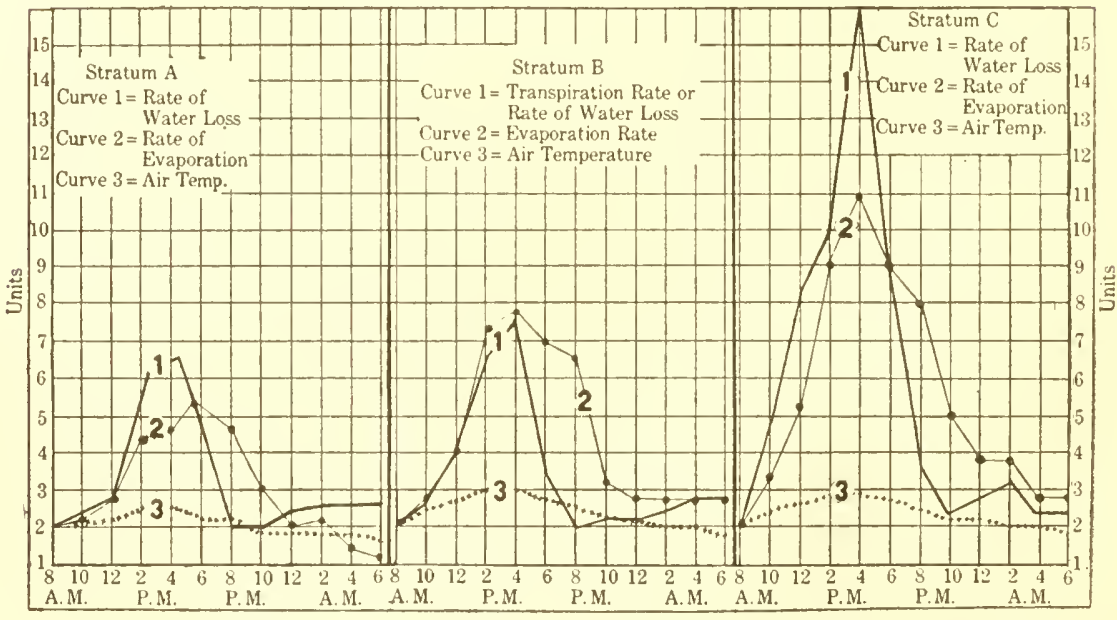

Fig, 2--Results recorded in table 5 reduced to unity and curves plotted in order to draw a closer comparison than is glven in figure 1. The same conclusions are self-evident. 
Figure 1 shows the plotted results for the data of this experiment. The broad, heavy lines give the results for stratum $\mathrm{A}$, the broken line, the results at stratum $B$, and the narrow line those for stratum C. The abscissæ represent the 2-hour time intervals, and each unit along the ordinate represents for the evaporation curves, 2.5 c. c.; for the transpiration curves in terms of entire weight, 3 per cent; for the transpiration curves in terms of dry weight, 13.5 per cent; for the relative humidity curves, 5 per cent; and for the temperature curves $2.5^{\circ} \mathrm{C}$. These graphs are interesting in that they show a close agreement between the evaporation-rate and transpiration curve for each stratum. Since the humidity and temperature curves coincide closely for the two upper strata, and the evaporation and transpiration curves for these strata vary in a similar direction, it appears that the rate of loss of water from the animals when exposed to the atmosphere agrees closely with the evaporation rates; $i$.e., the transpiration curves of these organisms, as Livingston (1906) found with plants, are largely controlled by the evaporating power of the air.

TABLE 6.-Summary of rate of evaporation in each stratum combined with loss of water from the beetle.

\begin{tabular}{|c|r|r|r|r|r|}
\hline \multicolumn{2}{|c|}{ Location. } & \multicolumn{2}{c|}{ Evaporation. } & \multicolumn{2}{c|}{ Transpiration. } \\
\cline { 2 - 5 } Stratum. & cm. & c. c. & Ratio. & Loss per cent $\mathrm{H}_{2} \mathrm{O}$. & Ratio. \\
\hline A & 5 & 35.3 & 1.0 & 47.2 & 1.0 \\
B & 60 & 60.3 & 1.7 & 71.3 & 1.5 \\
C & 90 & 119.1 & 3.4 & 113.9 & 2.4 \\
\hline
\end{tabular}

Figure 2 shows the water-loss in percentage, the evaporation-rates, and the air-temperatures, all reduced to unity. The broad, unbroken line represents the rate of water-loss in each case; the narrow, unbroken line, the evaporation rate for each stratum; and the broken line, the air-temperatures for each stratum. In making comparisons broadly, the air-temperatures agree in being represented by nearly straight lines, so that they were negligible; but the evaporation curves and curves of water-loss differ for each stratum, yet are similar when compared. At stratum A, the evaporation curve rises more rapidly and higher than the curve of water-loss, and the drop in the evaporation curve is faster than in the curve of water-loss. At stratum B, the curves of evaporation and of water-loss parallel each other until $6 \mathrm{p} . \mathrm{m}$. when the evaporation curve drops more suddenly. At stratum $\mathrm{C}$ the increased air-movement is an added factor in the environmental complex, so that both the water-loss and evaporation rates rise much higher, although the temperature curves remain the same. The curve of water-loss at stratum $\mathrm{C}$ rises more rapidly and higher than the evaporation curves. The latter drops sooner than the curve for evaporation. This appears to be due to the fact that the beetles are more sensitive to the environmental fluctuations than the porous-cup atmometer, so that difference might account for the lagging effect.

These differences iu the rate of evaporation in the three strata and the waterlosses are given in Table 6 . This table shows that approximately 1 c. c. loss from the cup is equal to 1 per cent loss of water from the beetles exposed. 
The evaporation rates here shown gave greater differences within this experimental cage than were obtained by Fuller (1911) for all the plant associations studied. Shelford (1912) uses Fuller's data with tables and compares them with conditions in certain animals, stating that distribution and succession of the animals is clearly correlated with evaporating power of air. By a further comparison with the description of stations, Shelford shows that the evaporating power of the air may be taken in this case as an index of materials, abode, and the like. Since the evaporation ratios existing inside of this cage filled with potato plants are greater than those obtained by Fuller for the stations such as Shelford used, it appeared that $L$. decemlineata reared in such

TABLe 7 .

\begin{tabular}{|c|c|c|c|c|c|c|c|c|c|c|c|c|c|}
\hline \multicolumn{5}{|c|}{$\begin{array}{l}\text { Environmental conditions } \\
\text { determined. }\end{array}$} & \multicolumn{9}{|c|}{ Leptinotarsa decemlineata subjected to desert conditions. } \\
\hline Time. & 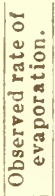 & 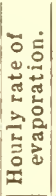 & 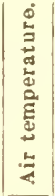 & 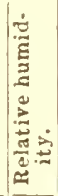 & 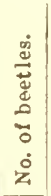 & 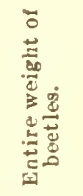 & 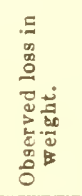 & 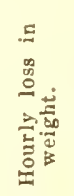 & 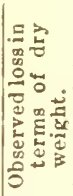 & 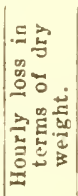 & 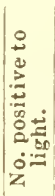 & 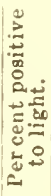 & General Remarks. \\
\hline & c. c. & c.c. & $\cdot \mathrm{c}$ & $\%$ & No. & $g \mathrm{~ms}$. & $g m$ & $m$ & $\% \mathrm{H}_{2} \mathrm{O}$ & $\% \mathrm{H}_{2} \mathrm{O}$ & No. & $\%$ & \\
\hline 10 a. m. & 0.0 & 0.0 & 30.2 & 52 & 25 & 3.4650 & 0.0000 & 0.0000 & 00.00 & 00.00 & 15 & 60 & \\
\hline $11 \mathrm{a} . \mathrm{m}$. & 2.1 & 2.1 & 31.4 & 49 & 25 & ........ & ....... & ....... & ....... & $\ldots .$. & 23 & 92 & \\
\hline 1 p. m. & 6.1 & 3.1 & 34.0 & 32 & 25 & $\ldots \ldots$ & ….. & & $\ldots \ldots$ & & 23 & 92 & \\
\hline 2 p. m. & 2.7 & 2.7 & 34.2 & 233 & 25 & 3.3270 & .1380 & .0345 & 15.03 & 3.76 & 15 & 60 & \\
\hline 3 p. m. & 3.1 & $\mid 3.1$ & 35.0 & D) 32 & 25 & & & & & & 21 & 84 & \\
\hline 4 p. m. & 3.9 & 3.9 & 37.7 & 32 & 25 & & ........ & $\ldots \ldots$ & $\cdots \cdots$ & ... & 21 & 84 & \\
\hline 5 p. m. & 3.2 & 3.2 & 35.6 & 33 & 25 & & $\ldots$ & ........ & & & 25 & 100 & \\
\hline $6 \mathrm{p.} \mathrm{m}$. & 4.3 & 4.3 & 34.2 & 31 & 25 & 3.2365 & .0905 & .0226 & 9.86 & 2.47 & 25 & 100 & \\
\hline 7 p. m. & 2.8 & 2.8 & 32.3 & 35 & 25 & & & & & & 25 & 100 & \\
\hline 10 p. m. & 5.2 & 1.7 & 28.3 & 46 & 25 & 3.1870 & .0495 & .0124 & 5.39 & 13.35 & 25 & 100 & \\
\hline 6 a. m. & 7.0 & 0.9 & 23.7 & 77 & 25 & 3.1490 & .0380 & .0050 & 4.14 & .52 & 24 & 96 & \\
\hline $10 \mathrm{a} . \mathrm{m}$. & 4.4 & 1.1 & 33.2 & 49 & 25 & 3.0725 & $.07 t$ & .019 & 8.33 & 2.08 & 24 & 96 & \\
\hline $2 \mathrm{p.m}$. & 14.8 & 3.7 & 22.5 & 32 & 25 & 2.9895 & .0830 & .0208 & 9.04 & 2.26 & 23 & 92 & \\
\hline $4 \mathrm{p.} \mathrm{m}$ & 6.0 & 3.0 & 32.4 & 42 & 25 & & & & & & 0 & 0 & Very cloudy. \\
\hline 5 p. m. & 0.0 & 0.0 & 22.8 & 390 & 25 & $(B e$ & tles inet & eased & urigh & t.) & 11 & 44 & Absorbed $\mathrm{H}_{2} \mathrm{O}$ from \\
\hline $6 \mathrm{p.} \mathrm{m}$. & 1.3 & 1.3 & 26.8 & 64 & 25 & 3.4230 & .4335 & .1168 & 47.22 & 11.81 & 21 & 84 & the air. \\
\hline 9 p. m. & 3.0 & 1.0 & 25.2 & 69 & 25 & 3.3940 & .02 & .0097 & 3.16 & 1.05 & 25 & 100 & \\
\hline $12 \mathrm{p.m}$. & 4.3 & 1.4 & 23.4 & 73 & 25 & 3.3715 & .022 & .0075 & 2.45 & .82 & 25 & 100 & \\
\hline 3 a. m. & 1.7 & 0.6 & 23.5 & 70 & 25 & 3.3540 & .01 ? & .0058 & 1.91 & .61 & 25 & 100 & \\
\hline $6 \mathrm{a} . \mathrm{m}$. & 2.0 & 0.7 & 22.7 & 82 & 25 & 3.3295 & .024 & .0082 & 2.67 & .89 & 25 & 100 & \\
\hline 9 a. m. & 1.8 & 0.6 & 28.6 & 66 & 25 & 3.2 & .04 & .0138 & 4.52 & 1.51 & 23 & 92 & \\
\hline $12 \mathrm{a} . \mathrm{m}$. & 6.4 & 2.1 & 31.4 & 41 & 25 & 3.18 & .1055 & .0352 & 11.43 & 3.83 & 22 & 88 & \\
\hline 3 p. m. & 9.7 & 3.2 & 33.6 & 42 & 25 & 3.0840 & .0985 & .0328 & 10.73 & 3.58 & 21 & 84 & $0.0705 \mathrm{gm}$. deducted for \\
\hline $6 \mathrm{p.m}$. & 6.7 & 2.2 & 31.2 & 43 & 23 & 2.94 & .073 & .0243 & 8.42 & 2.81 & 14 & 61 & 2 died. \\
\hline 9 p. m. & 6.2 & 2.1 & 28.0 & 52 & 23 & 2.9035 & .0370 & .0123 & 4.27 & 1.42 & 16 & 70 & \\
\hline $12 \mathrm{p.} \mathrm{m}$. & 3.5 & 1.2 & 26.3 & 62 & 23 & 2.8800 & .0235 & .0078 & 2.71 & $|\quad .90|$ & 17 & 74 & \\
\hline 6 a. $\mathrm{m}$. & 8.9 & 0.7 & 24.3 & 72 & es & 2.8935 & .0135 & (Beet & es abso & $\mathrm{rb} \mathrm{H}_{2} \mathrm{O}$ & b). & 78 & Absorbed $\mathrm{H}_{2} \mathrm{O}$ from \\
\hline 6 p. m. & 13.4 & 1.1 & 24.1 & $9 z$ & Es & 3.2695 & .9769 & .0914 & 48.17 & 1 & 18 & 100 & the air. \\
\hline
\end{tabular}

a cage has a great range of adaptability. From the base of the potato plants to just a little above their tops, there existed zones of evaporation of wide extremes. To illustrate, Table 5 shows that from 2 to $4 \mathrm{p}$. m. at stratum $\mathrm{A}$ the evaporationrate was 4.6 c. c. and loss in water-weight of beetles was 7.9 per cent of their entire weight; at stratum $B$ the evaporation rate was 8.9 c. c. and loss of weight of animals exposed, 13.46 per cent; and at stratum $\mathrm{C}$ the rate was 19.4 c. c. and loss in weight of the beetles was 26.82 per cent. This shows the evaporation ratios to be $1.00: 1.93: 4.22$, and the transpiration ratios to be $1.0: 1.7: 3.4$. For the whole experiment, the ratios of evaporation were $1.0: 1.7: 3.4$, while the transpiration ratios were $1.0: 1.5: 2.4$. In general, these ratios are very similar, showing that there is a direct relation between the evaporation-rates and transpiration percentages, and it answers in part the question already raised: Do 
the evaporation-rates, the transpiration curves, and the reaction graphs of these organisms correspond? The following experiments give us a further affirmative response by showing that such a correspondence does exist in the potato-beetle and other insects.

The first experiment was performed out-of-doors at the foot of Tumamoc hill near the experimental cages at Tucson Station A. The beetles which had newly emerged from the pupa state were collected at night. They were kept under saturated bell jars at a constant temperature until morning when they were placed in wire netting tubes. At $11 \mathrm{a} . \mathrm{m}$. on July 19 they were exposed to the desert conditions in the open until $6 \mathrm{p}$. m. on July 21. The following environmental conditions were determined hourly : the rate of evaporation, the

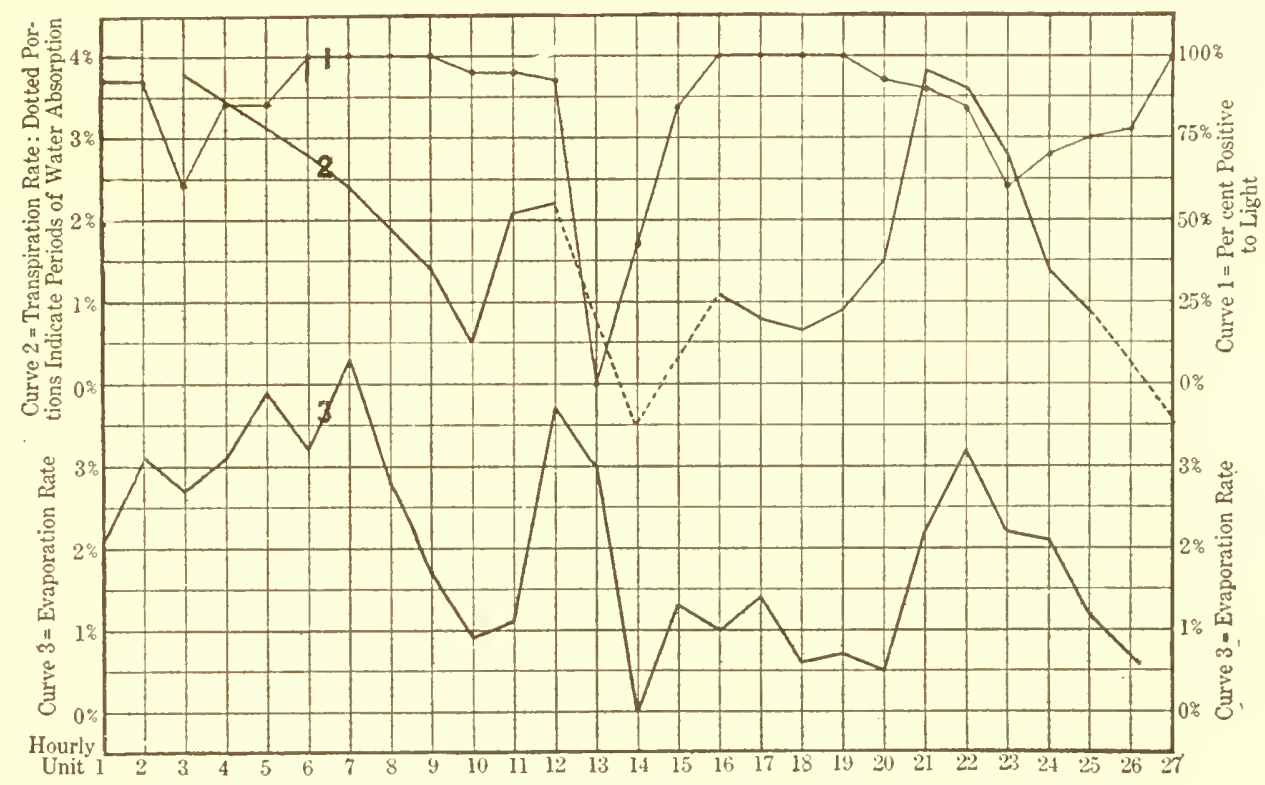

Fig. 3-Curves 2 and 3 show the relation of evaporation to transpiration (water-loss) of beetles when exposed out-of-doors at the foot of Tumamoc hill; however, Curve 1 shows that the reactions of this insect to light were in general the reciprocal of the evaporation and transpiration curves.

air temperature, and the relative humidity. During this experiment, the entire weight of the beetles was also determined, as well as periods when these insects gave off water to the atmosphere. It is of importance to plant and animal physiologists to state that these beetles absorbed water directly from the atmosphere. Aside from these determinations, others were made, which include the hourly loss in weight of these insects, the observed loss of water in terms of their dry weight, the daily loss of water in terms of dry weight, and the number of the beetles which were positive to light as well as the percentage positive to light. These results are given in Table 7 and the figures in italies in Table 7 show periods when the beetles absorbed water directly from the air. The evaporation rates and the transpiration and reaction rates of Leptinotarsa are plotted in figure 3. 
By consulting this figure, one can see at a glance that the curves for transpiration and evaporation correspond. Moreover, the reciprocal of the reaction or behavior curve also corresponds to these curves in a similar manner. Thus in the reaction of the potato beetle, its percentages of positiveness was, broadly speaking, the reciprocal of the transpiration curve. This seems to show that the loss of water from the animal, when exposed in the open, determined the reactions of the insect.

TABLE 8.-Results of subjecting other insects to the same environmental conditions as Leptinotarsa decemlineata.

\begin{tabular}{|c|c|c|c|c|c|c|c|c|c|c|}
\hline $\begin{array}{l}\operatorname{In}- \\
\operatorname{sect} \theta .\end{array}$ & Time. & 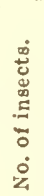 & 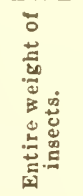 & 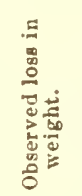 & 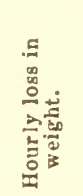 & 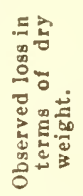 & 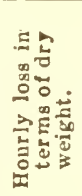 & 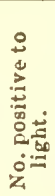 & 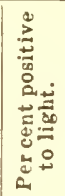 & General Remarks. \\
\hline 总 & $\begin{array}{r}10 \text { \&. m. } \\
11 \text { a. m. } \\
1 \text { p. m. } \\
2 \text { p. m. } \\
3 \text { p. m. } \\
4 \text { p. m. } \\
5 \text { p. m. } \\
6 \text { p. m. } \\
7 \text { p. m. } \\
10 \text { p. m. } \\
6 \text { a. m. } \\
10 \text { a. m. }\end{array}$ & $\begin{array}{l}\text { No. } \\
10 \\
10 \\
10 \\
10 \\
10 \\
10 \\
10 \\
10 \\
10 \\
10 \\
10 \\
10\end{array}$ & 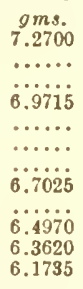 & $\begin{array}{c}g m s . \\
0.0000 \\
\ldots \ldots \\
\ldots \ldots 30 \\
.2985 \\
\ldots \ldots \ldots \\
\ldots \ldots \ldots \\
.2690 \\
.205 \\
.2055 \\
.1350 \\
.1885\end{array}$ & $\begin{array}{c}g m s . \\
0.0000 \\
\ldots \ldots \\
\ldots \ldots 76 \\
.0746 \\
\ldots \ldots \ldots \\
\ldots \ldots \ldots \\
.0675 \\
.0514 \\
.0170 \\
.0471\end{array}$ & $\begin{array}{r}\% \mathrm{H}_{2} \mathrm{O} \\
0.00 \\
\ldots \ldots . \\
\ldots \ldots . \\
11.09 \\
\ldots \ldots \ldots \\
\ldots \ldots \ldots \\
10.34 \\
\ldots .90 \\
5.19 \\
7.25\end{array}$ & $\begin{array}{c}\% \mathrm{H}_{2} \mathrm{O} \\
0.00 \\
\ldots . \\
\ldots .77 \\
\ldots \ldots \\
\ldots \ldots \\
\dddot{2.59} \\
\dddot{1} .98 \\
0.65 \\
1.81\end{array}$ & $\begin{array}{r}\text { No. } \\
9 \\
10 \\
10 \\
10 \\
10 \\
10 \\
10 \\
10 \\
10 \\
0 \\
0 \\
0\end{array}$ & $\begin{array}{r}p . c t . \\
90 \\
100 \\
100 \\
100 \\
100 \\
100 \\
100 \\
100 \\
100 \\
0 \\
0 \\
0\end{array}$ & All dead. \\
\hline 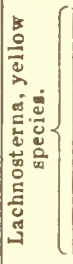 & $\begin{array}{r}10 \text { a. m. } \\
11 \text { a. m. } \\
1 \text { p. m. } \\
2 \text { p. m. } \\
3 \text { p. m. } \\
4 \text { p. m. } \\
5 \text { p. m. } \\
6 \text { p. m. } \\
7 \text { p. m. } \\
10 \text { p. m. } \\
6 \text { a. m. } \\
10 \text { a. m. }\end{array}$ & \begin{tabular}{|r}
16 \\
16 \\
16 \\
16 \\
13 \\
13 \\
13 \\
13 \\
8 \\
8 \\
6 \\
6
\end{tabular} & $\begin{array}{l}2.1790 \\
\ldots \ldots . \\
\ldots \ldots .6 \\
1.9900 \\
\ldots \ldots . \\
\ldots \ldots . \\
1.5715 \\
\ldots \ldots .0 \\
1.0545 \\
0.8030 \\
\ldots \ldots\end{array}$ & $\begin{array}{c}0.0000 \\
\ldots \ldots . \\
\ldots \ldots .6 \\
.1890 \\
\ldots \ldots . \\
\ldots \ldots . \\
\ldots .184 \\
\ldots \ldots \\
.0575 \\
.0290 \\
\ldots \ldots\end{array}$ & $\begin{array}{c}0.0000 \\
\ldots \ldots . . \\
\ldots .04 \\
.0473 \\
\ldots \ldots . \\
\ldots \ldots . \\
.0461 \\
\ldots \ldots . \\
.0144 \\
.0036 \\
\ldots \ldots\end{array}$ & $\begin{array}{r}0.00 \\
\ldots \ldots . \\
\ldots 2.16 \\
\ldots \ldots . \\
\ldots \ldots . \\
\ldots \ldots .21 \\
\ldots \ldots . \\
10.23 \\
7.30 \\
\ldots \ldots\end{array}$ & 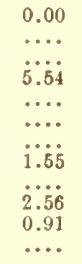 & $\begin{array}{l}0 \\
0 \\
0 \\
0 \\
0 \\
0 \\
0 \\
0 \\
0 \\
0 \\
0 \\
0\end{array}$ & $\begin{array}{l}0 \\
0 \\
0 \\
0 \\
0 \\
0 \\
0 \\
0 \\
0 \\
0 \\
0 \\
0\end{array}$ & $\begin{array}{l}3 \text { dead; deduct } 0.235 \mathrm{gm} \text {. } \\
5 \mathrm{~d} \epsilon \mathrm{ad}=0.4595 \mathrm{gm} . \\
2 \text { dead }=0.2225 \mathrm{gm} . \\
\text { All dead. }\end{array}$ \\
\hline 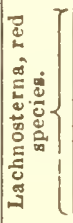 & $\begin{aligned} & 10 \text { a. m. } \\
& 11 \text { a. m. } \\
& 1 \text { p. m. } \\
& 2 \text { p. m. } \\
& 3 \text { p. m. } \\
& 4 \text { p. m. } \\
& 5 \text { p. m. } \\
& 6 \text { p. m. } \\
& 7 \text { p. m. } \\
& 10 \text { p. m. }\end{aligned}$ & $\begin{array}{l}8 \\
8 \\
8 \\
8 \\
6 \\
6 \\
6 \\
4 \\
4 \\
4\end{array}$ & $\begin{array}{l}2.9510 \\
\ldots \ldots \\
\ldots \ldots 30 \\
2.7845 \\
\ldots \ldots \\
\dddot{1.9440} \\
\ldots \ldots \ldots \\
1.3055 \\
1.2705\end{array}$ & $\begin{array}{l}0.0000 \\
\ldots \ldots \\
\cdots \ldots \\
.1665 \\
\ldots \ldots \\
\ldots . \cdots \\
.0880 \\
\ldots \ldots \\
.0380 \\
.0350\end{array}$ & $\begin{array}{l}0.0000 \\
\ldots \ldots \\
\ldots .04 \\
.0416 \\
\ldots \ldots \\
.020 \\
\ldots \ldots \\
.0095 \\
.0044\end{array}$ & 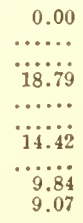 & $\begin{array}{l}0.00 \\
\ldots . . \\
\dddot{4} .70 \\
\ldots \ldots \\
\dddot{3} .61 \\
\ldots .0 \\
\ddot{2.46} \\
1.13\end{array}$ & $\begin{array}{l}0 \\
0 \\
0 \\
0 \\
0 \\
0 \\
0 \\
0 \\
0 \\
0\end{array}$ & $\begin{array}{l}0 \\
0 \\
0 \\
0 \\
0 \\
0 \\
0 \\
0 \\
0 \\
0\end{array}$ & $\begin{array}{l}2 \text { dead }=0.7525 \mathrm{gm} \\
2 \text { dead }=0.6005 \mathrm{gm} \\
\text { All dead. }\end{array}$ \\
\hline 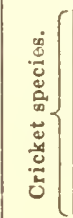 & $\begin{array}{r}10 \text { a. m. } \\
11 \text { a. m. } \\
1 \text { p. m. } \\
2 \text { p. m. } \\
3 \text { p. m. } \\
4 \text { p. m. } \\
5 \text { p. m. } \\
6 \text { p. m. } \\
7 \text { p. m. } \\
10 \text { p. m. }\end{array}$ & $\begin{array}{l}9 \\
9 \\
9 \\
9 \\
9 \\
9 \\
9 \\
9 \\
9 \\
8 \\
8\end{array}$ & $\begin{array}{l}5.1725 \\
\ldots \ldots . \\
\ldots \ldots .6 \\
4.8263 \\
\ldots \ldots \ldots \\
\ldots \ldots \ldots \\
4.6005 \\
\ldots \ldots 30 \\
4.0340\end{array}$ & 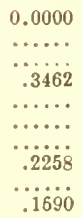 & 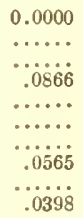 & 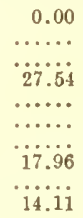 & $\begin{array}{l}0.00 \\
\ldots \ldots \\
\ldots . .89 \\
\ldots . \\
\ldots \ldots \\
\ldots .49 \\
\ldots . .9 \\
3.53\end{array}$ & $\begin{array}{l}5 \\
5 \\
8 \\
4 \\
4 \\
5 \\
4 \\
3 \\
0 \\
0\end{array}$ & $\begin{array}{r}56 \\
56 \\
89 \\
44 \\
44 \\
56 \\
44 \\
33 \\
0 \\
0\end{array}$ & $\begin{array}{l}1 \text { dead }=0.4075 \mathrm{gm} \text {. } \\
\text { All dead. }\end{array}$ \\
\hline
\end{tabular}

The second experiment was performed to determine the relation of evaporation to the transpiration and reactions of insects when exposed for several days under natural conditions. To get a comparison between $L$. decemlineata and other insects, a cricket (Gryllus), a beetle (Catalpa lanigera), and two species of June-bugs (Lachnosternæ) were used, since they could be collected in large numbers. 'These insects, with the exception of the potato-beetles, were obtained 
at night by aid of a light, and were collected as soon as possible after emergence. All were placed at once in bell-jars in the constant-temperature room. A high relative humidity was produced as before by placing a wet filter-paper inside the jars, which permitted the animals, if not already saturated, to absorb water, so that their water-contents would be as uniform as possible, and they would attain, in this respect, a similar physiological equilibrium. The insects were retained under these conditions until $10 \mathrm{a} . \mathrm{m}$. the following morning, when they were exposed in similar cylindrical tubes. The instruments for measuring environmental conditions were also placed in these tubes, which were suspended to a wire and placed in the open, so that each tube was inclined toward the north. The direct rays of the sun were thus permitted to fall upon the tubes at right angles. Unless otherwise indicated in Table 8, the observations were made hourly from 11 a. m. July 19 to 6 p. m. July 21, and for the environmental couditions consult Table $\%$.

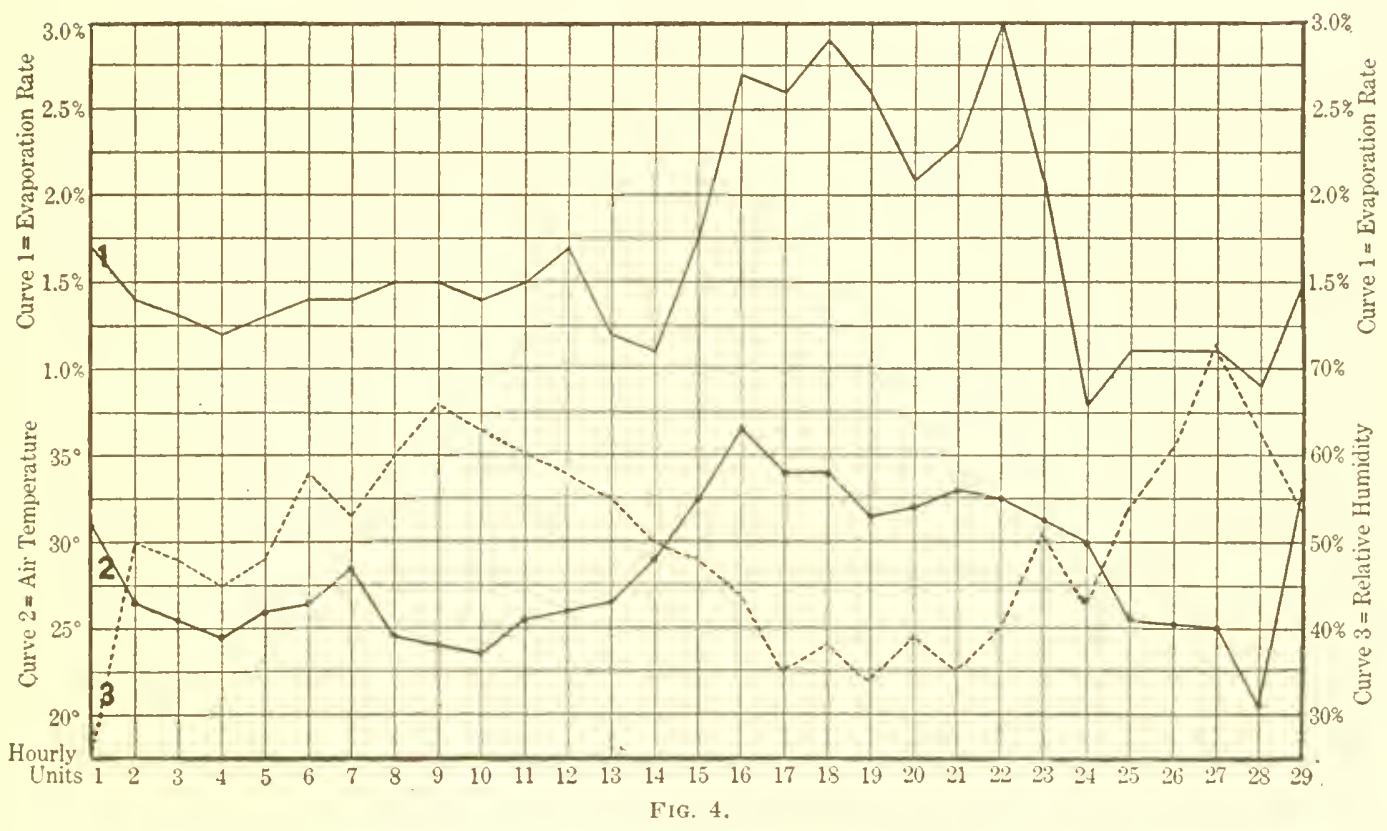

If one should plot the results given in Table 8 , he will find that all of the organisms used give a transpiration curve which corresponds with their curves of evaporation. Catalpa lanigera and the erickets reacted to transpiration in a manner not unlike the potato beetles, while the Lachnosternæ always gave a negative response, regardless of conditions.

Another experiment upon loss of water and insect activity was made as a conformatory test, in which the methods and materials used were similar. The animals consisted of $31 \mathrm{~L}$. decemlineata (Tucson A, g. III), 10 Catalpa lanigera, and 20 Lachnosternæ. The latter were collected around an electric light and then placed in a refrigerator. All instruments and insects were exposed in the open in large netting spheres and hourly observations were made from 9 p. m. August 9 to 4 p. m. August 11; the complete data are given in Table 9. The evaporation-rates, the air-temperatures, and the relative humidities are 


\begin{tabular}{|c|c|c|}
\hline \multirow{7}{*}{ 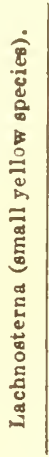 } & 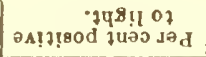 & 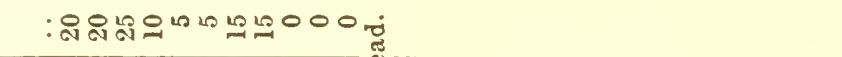 \\
\hline & $\begin{array}{l}\cdot 749 ! 1 \\
07 \text { an! } 1 ! \operatorname{sod} 0^{\circ}\end{array}$ & 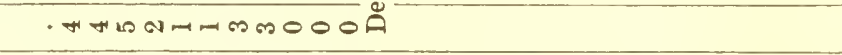 \\
\hline & 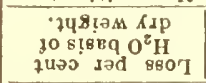 & 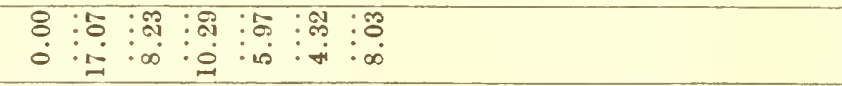 \\
\hline & 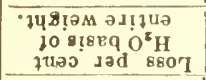 & 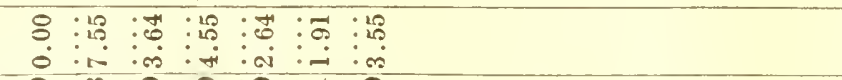 \\
\hline & 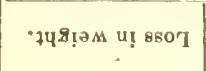 & 㴽 \\
\hline & 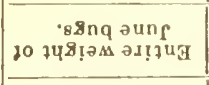 & 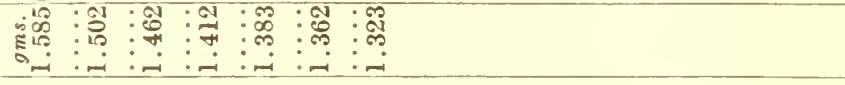 \\
\hline & $\Leftrightarrow 8 \sin$ əunt $20.0 \mathrm{~N}$ & 유유유유유유유్ \\
\hline \multirow{7}{*}{ 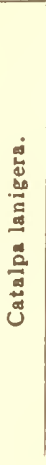 } & 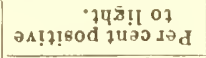 & 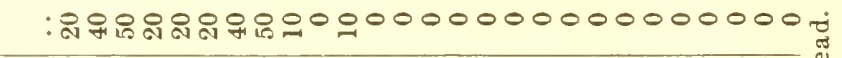 \\
\hline & 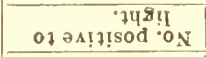 & . nth \\
\hline & 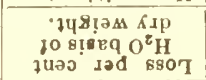 & 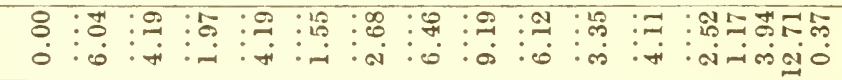 \\
\hline & 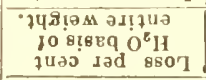 & \& \\
\hline & วบ & है: \\
\hline & 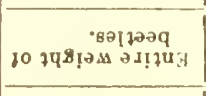 & 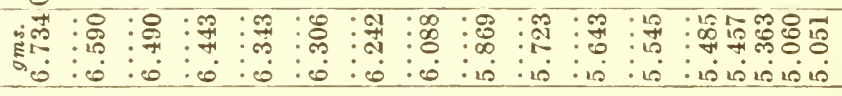 \\
\hline & 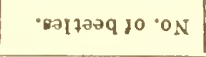 & 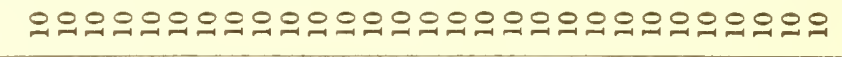 \\
\hline \multirow{7}{*}{ 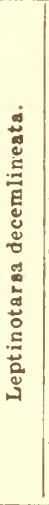 } & 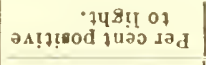 & : \\
\hline & $\begin{array}{c}\cdot 748 ! 1 \\
07 \theta \Delta ! 2 ! \operatorname{sod}: 0_{N} \\
\end{array}$ & :어쉄요 \\
\hline & 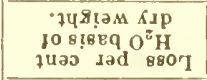 & 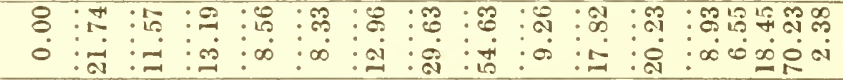 \\
\hline & 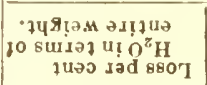 & 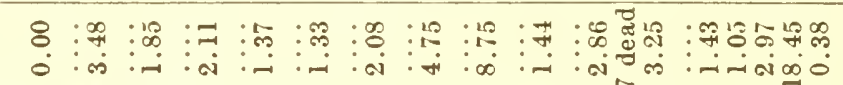 \\
\hline & 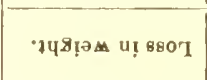 & 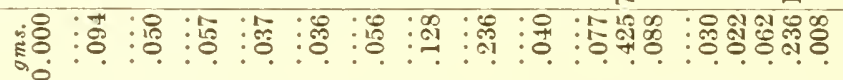 \\
\hline & 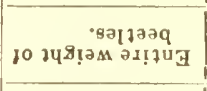 & 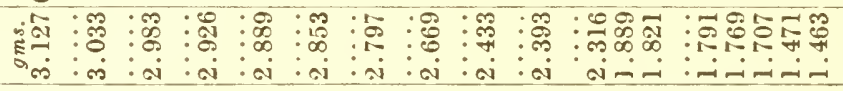 \\
\hline & $\cdot \operatorname{satzagq~zo.~ON~}$ & 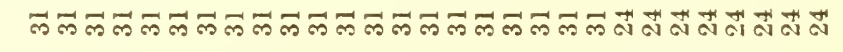 \\
\hline \multirow{6}{*}{ 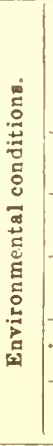 } & • $\mathrm{A}$ भS & 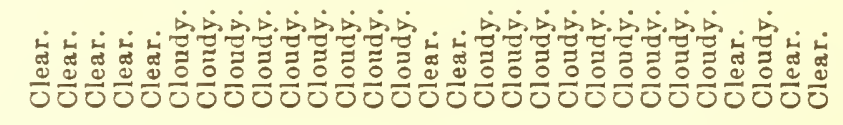 \\
\hline & 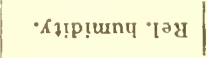 & 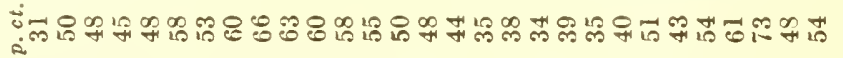 \\
\hline & -qInq zaM & 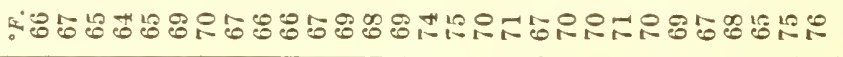 \\
\hline & 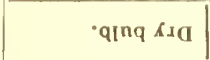 & 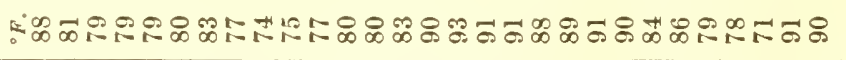 \\
\hline & -asnzвдаduaz נו̣ & on \\
\hline & 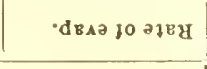 & 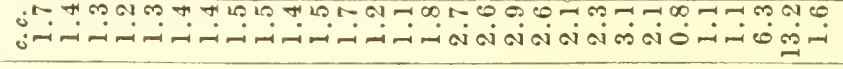 \\
\hline & 兽 & 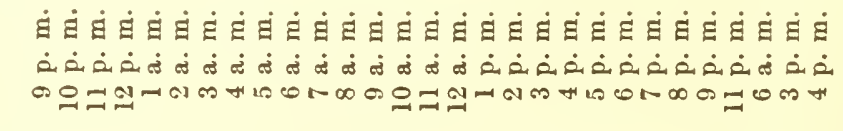 \\
\hline
\end{tabular}


shown in figure 4, while the transpiration and reaction curves of Leptinotarsa decemlineata and Catalpa lanigera are given in figure 5. The upper diagram contrasts for the potato beetle its transpiration rate with the percentage positive to light, while the lower half of the cut does the same thing for Catalpa lanigera. This experiment was similar to the former ones, in that the insects were subjected to the environmental conditions out-of-doors at the foot of Tumamoc hill.

For other data and comparisons Table 9 should be consulted; the results given show that the evaporation curve as measured by the porous-cup atmometer and the transpiration curves of the insects are similar, as was previously found to be true. Moreover, the positive reaction curve of the potato beetle was the

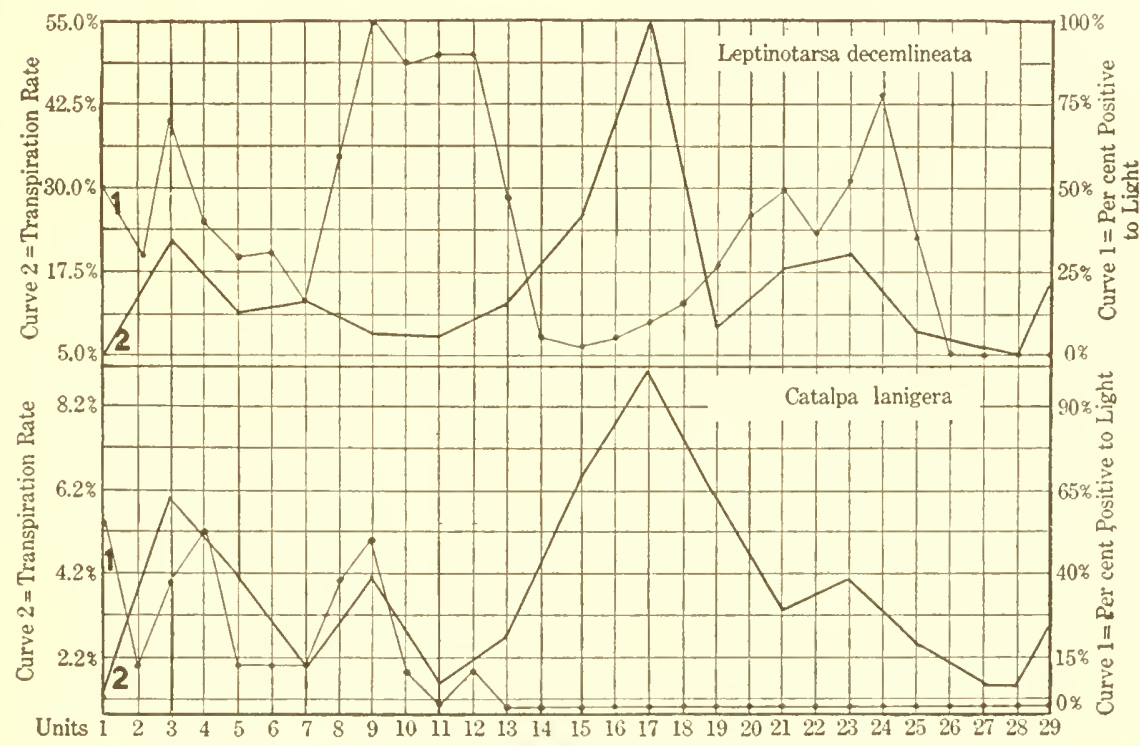

FIG. 5 .

reciprocal of its transpiration curve. In the same way the reaction curve of C. lanigera was associated with its transpiration curve until 9 a. m., when all reactions became negative. The Lachnosternæ appeared here only with a negative reaction, regardless of their transpiration curve, which agreed with the curve of evaporation.

These results prove, in the first instance, that the evaporating power of the air was the determining factor in the transpiration of these animals, a result similar to that obtained by Livingston (1906) for plants; secondly, that there existed from the base to the top of associated plants, in an arid region, an extreme zonation, in which great differences were found in the evaporating power of the air, and that this in turn controlled the rate of transpiration; and finally, that the evaporating power of the air surrounding the organisms determined their behavior through transpiration. Moreover, many animal organisms of the desert exhibited great localization in their distribution and the ruling feature of the environmental complex, whether it entailed a habitat of trees, among rocks, or in soils, was that of the moisture-relation. 


\section{RÔLE OF WATER IN HIBERNATION.}

It is an established fact (Tower, 1906) that in the second or winter generation Leptinotarsa decemlineata in its homozygous state always hibernates under normal conditions, but that desiccation, or cold, or both, might produce hibernation at any time. At Tucson it was also found that whenever the conditions became adverse enough to produce desiccation, hibernation was produced. Tower (1906) showed that preparation for hibernation in the winter generation consists largely in the reduction of the watery contents of the body and in an elimination of all food and other substances from the alimentary canal.

These facts indicated that the loss of water appeared to be produced by two different mechanisms. One was controlled by an external medium, while the other was determined by heredity. In the former, water was extracted from the tissues through desiccation due to conditions in the medium, while in the latter water was eliminated from the tissues through internal processes under normal conditions. Tower states:

"Preparation for hibernation consists in a physiological change in the constitution of the body for the time being and a consequent lowering of the freezing-point of its tissues in exactly the same way that spores of many plants and the over-wintering eggs of rotifers prepare for the coming of the unfavorable conditions in their environment."

The following experiments were performed to show how the above results can be brought about through desiccation. At Tucson this type of hibernation was quite common, but did not occur in nature at Chicago.

\section{ENTRANCE INTO HIBERNATION.}

It is evident that in the potato beetle entrance into hibernation may be "induced hibernation," which occurred whenever the evaporating power of the air surrounding the insect removed more water by weight in a given time than was introduced into the organism by food and other agencies. Such desiccation produced in the course of one or two days depended upon the adversity of the conditions, thus effecting change in the beetle's behavior, so that its reactions were reversed and it burrowed in the soil.

Extensive observations were made at Tucson Station A, where it was discovered that this type of hibernation took place whenever sufficiently desiccating conditions existed. The evidence of such a reaction in a large population was determined by comparing the daily environmental readings with counts of the non-hibernating population, which showed that during the rainy season and as long as water was added to the soil no entrance in this type was found, but when water was discontinued desiccation occurred and hibernation resulted. On the other hand, at Tucson Station B, the "induced hibernation" was always observed as the prevailing type of behavior, since in this habitat the conditions were more adverse. Moreover, at this locality, the growth of the food plants was retarded, since the leaves were tougher and showed less water-content; desiccation was also much greater, so that the response of the organisms to such rigorous conditions was sharper than in any other locality under observation. This clearly demonstrated when a comparison of the daily environmental records were made with the daily count of beetles, which were found out of the 
ground during one month of the rainy season. At Chicago, however, no induced entrance was discovered, since the conditions were more favorable there for normal activities, as the daily environmental readings indicate. From these observations it is evident that a type of hibernation occurred during periods of low water-content in the surrounding medium; this produced a lowering of the beetles' content and induced a set of reactions so that a type of behavior, potentially hibernation, resulted; to determine exactly the rôle of water-loss in the observed reactions other experimental tests were performed.

For the purposes of this particular problem, the first test consisted of inducing rstivation by desiccating adults of the summer generation, which do not normally hibernate. The beetles for this experiment consisted of 259 adults (Tucson A, g. III) which had been placed in a culture cage filled with potato plants. They were allowed to feed until July 15, when a few bunches of eggs were deposited, and at 4 p. m. 200 of these beetles were collected and divided into two groups of 100 each, regardless of sex. The beetles were weighed, group A weighing 12.16 grams and group B 11.52 grams, respectively. Group A was now placed under a bell-jar with calcium chloride and group B under a similar jar filled with wet filter-paper. The jars with the beetles were placed side by side in an adobe building under identical conditions, except for differences in the desiccating capacity of the medium within the bell-jars. Throughout the experiment the temperatures ranged from $26^{\circ}$ to $38^{\circ} \mathrm{C}$. At $8 \mathrm{p} . \mathrm{m}$. July 24 these insects were removed from the soil in the bell-jar and reweighed. Group A from the desiccator weighed 8.53 grams, showing a loss of 3.63 grams, and group $B$ from the humidor weighed 10.92 grams. Previously a box of soil (90 by 60 by $15 \mathrm{~cm}$.) had been filled with a mixture of equal parts of sand and adobe, which also had been already saturated with water and was kept slightly moist throughout the experiment. Two bell-jars (a humidor and a desiccator) were placed side by side over the slightly moist soil in the above box; insects of group A were placed in the latter, and those of group B in the former; after 28 hours group A was in hibernation, but group B did not hibernate, although the beetles remained active upon the filter-paper. The calcium chloride was now removed from the bell-jar over the hibernated group A, and the soil was kept saturated; at the end of 3 days 12 beetles emerged and after 6 days 57 more beetles were discovered, but at the end of 2 days no others had emerged; the soil was then sifted and 31 dead beetles were found. The individuals of group $B$ still remained active, but none, however, had hibernated. These results show clearly that in the summer generation "induced" hibernation with a high death-rate may be produced through desiccation and, furthermore, that when water-balances were restored, all the living individuals emerged again and resumed the activities normal to their generation and season.

To further substantiate the above conclusions other tests follow. In the fall generation, which hibernates normally, 1,000 newly emerged adults (Tucson A, g. IV) were collected on August 14, and divided equally, regardless of sex, into the following four groups: Each group was placed immediately in a separate wire-netting tube in the screened vivarium at Station $\mathbf{A}$, and the tubes were made of wire-netting $(95 \mathrm{~cm}$. deep and $35 \mathrm{~cm}$. in diameter $)$, with a similar material covering the top. These were sunk $55 \mathrm{~cm}$. into adobe soil composing the bottom of the vivarium, and each tube was filled to a depth of $53 \mathrm{~cm}$. with a mixture of equal parts of sand and adobe. 
The following conditions were experimentally planned in tube 1 , containing 250 beetles, to give a low rate of evaporation, and the soil was kept moist by adding water each morning and evening. This tube was kept filled with sprays of Solanum hertwigii, which were kept fresh by having the stems in $250 \mathrm{c}$. c. bottles filled with water, and the sprays were renewed twice daily; it was also necessary to wrap tinfoil about the top of the bottles to prevent the beetles from drowning: The environmental conditions were apparently normal, for the

TABLE 10.

\begin{tabular}{|c|c|c|c|c|c|c|c|c|c|c|c|c|c|c|c|c|}
\hline \multirow[b]{2}{*}{ When observed. } & \multicolumn{4}{|c|}{$\begin{array}{l}\text { Tube } 1 . \\
\text { Food and moist. }\end{array}$} & \multicolumn{4}{|c|}{$\begin{array}{l}\text { Tube } 2 . \\
\text { Food and dry. }\end{array}$} & \multicolumn{4}{|c|}{$\begin{array}{l}\text { Tube } 3 \text {. } \\
\text { No lood and dry. }\end{array}$} & \multicolumn{4}{|c|}{$\begin{array}{l}\text { Tube } 4 . \\
\text { No food but moist. }\end{array}$} \\
\hline & 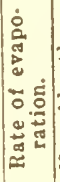 & 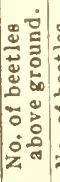 & 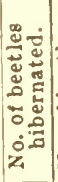 & 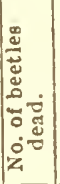 & 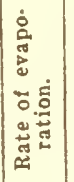 & 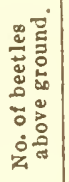 & 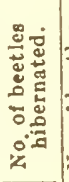 & 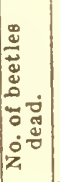 & 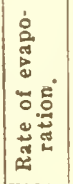 & 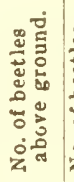 & 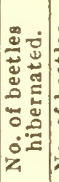 & 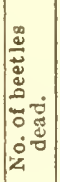 & 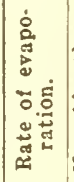 & 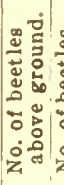 & 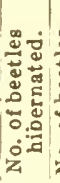 & 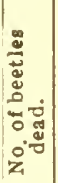 \\
\hline 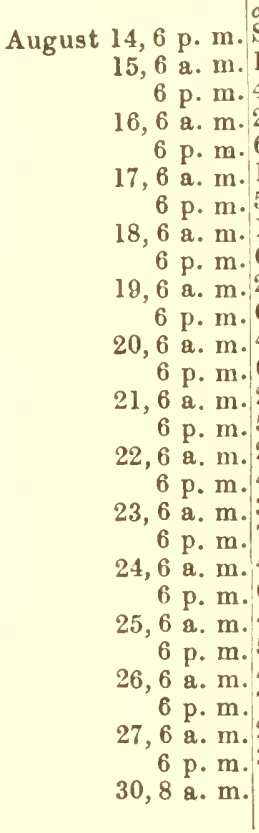 & $\begin{array}{l}c . c \\
\text { Set } \\
1.2 \\
4.3 \\
2.0 \\
6.1 \\
1.0 \\
5.7 \\
1.1 \\
6.2 \\
2.1 \\
6.4 \\
4.0 \\
6.8 \\
2.2 \\
5.9 \\
2.1 \\
4.6 \\
3.0 \\
7.1 \\
4.9 \\
6.1 \\
4.0 \\
5.6 \\
4.1 \\
7.0 \\
2.0 \\
3.2 \\
4\end{array}$ & \begin{tabular}{|l|}
250 \\
$\cdots$ \\
$\cdots$ \\
250 \\
$\cdots$ \\
$\cdots$ \\
250 \\
$\cdots$ \\
$\cdots$ \\
248 \\
$\cdots$ \\
$\cdots$ \\
$\cdots$ \\
245 \\
$\cdots$ \\
$\cdots$ \\
241 \\
$\cdots$ \\
$\cdots$ \\
$\cdots$ \\
$\cdots$ \\
222 \\
$T$ \\
\end{tabular} & $\begin{array}{c}0 \\
\cdots \\
\cdots \\
0 \\
\ldots \\
\ldots \\
0 \\
\cdots \\
0 \\
0 \\
\ldots \\
0 \\
\ldots \\
\ldots \\
0 \\
\ldots \\
\cdots \\
\ldots \\
\cdots \\
0\end{array}$ & 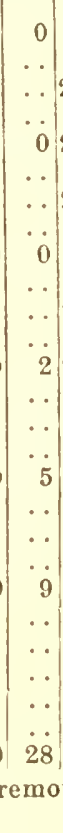 & \begin{tabular}{|r}
$r \cdot c$. \\
Set \\
6.0 \\
21.2 \\
4.3 \\
22.0 \\
4.1 \\
21.2 \\
5.0 \\
19.1 \\
6.3 \\
22.2 \\
7.0 \\
26.9 \\
6.3 \\
25.2 \\
5.2 \\
21.3 \\
4.6 \\
18.3 \\
6.3 \\
24.6 \\
5.3 \\
24.2 \\
6.1 \\
23.8 \\
6.0 \\
18.2 \\
$v e d$, \\
\end{tabular} & $\begin{array}{c}250 \\
\ldots \\
\ldots \\
249 \\
\ldots \\
\ldots \\
241 \\
\ldots \\
\ldots \\
124 \\
\cdots \\
\cdots \\
\cdots 3 \\
\ldots \\
\ldots \\
\ldots \\
0 \\
\ldots \\
\ldots \\
\ldots \\
\ldots \\
0\end{array}$ & $\begin{array}{c}0 \\
\ldots \\
\ldots \\
\ldots \\
0 \\
\ldots \\
\ldots \\
\ldots \\
7 \\
\ldots \\
\ldots \\
\ldots \\
85 \\
\ldots \\
\ldots \\
121 \\
\ldots \\
\ldots \\
157 \\
\ldots \\
\ldots \\
\ldots \\
\ldots \\
157 \\
\end{array}$ & 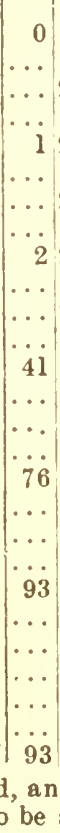 & \begin{tabular}{|r|}
$r_{\text {Set }}^{c}$ \\
6.9 \\
22.7 \\
5.9 \\
23.7 \\
4.9 \\
24.7 \\
5.9 \\
21.8 \\
6.7 \\
22.7 \\
6.9 \\
23.7 \\
5.9 \\
24.7 \\
5.0 \\
21.7 \\
5.0 \\
20.7 \\
5.9 \\
19.8 \\
5.0 \\
21.7 \\
5.9 \\
22.8 \\
6.7 \\
23.0 \\
$\mathrm{nd}$ all \\
$\mathrm{alive}$
\end{tabular} & 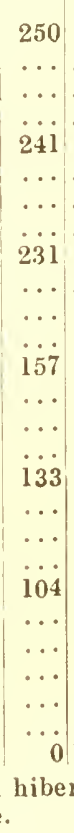 & 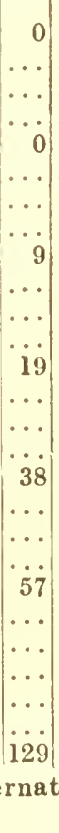 & 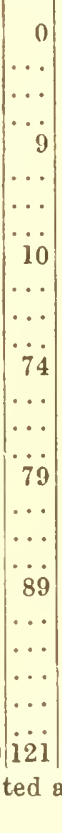 & \begin{tabular}{|l}
$c . c$. \\
Set \\
1.8 \\
6.4 \\
2.8 \\
8.2 \\
1.8 \\
7.3 \\
1.8 \\
8.2 \\
2.8 \\
9.2 \\
5.5 \\
8.2 \\
3.7 \\
8.2 \\
3.7 \\
7.3 \\
4.6 \\
9.2 \\
5.5 \\
7.3 \\
5.5 \\
7.3 \\
5.5 \\
8.2 \\
3.7 \\
1.5 \\
adult
\end{tabular} & 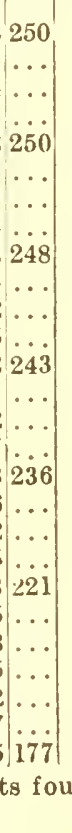 & 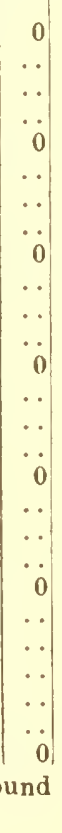 & $\begin{array}{c}0 \\
\ldots \\
\ldots \\
0 \\
\ldots \\
\ldots \\
2 \\
\ldots \\
\ldots \\
17 \\
\ldots \\
\ldots \\
14 \\
\ldots \\
\ldots \\
29 \\
\ldots \\
\ldots \\
\ldots \\
73 \\
\end{array}$ \\
\hline
\end{tabular}

water-condition, the food-supply, the low rate of evaporation, and the soilmoisture were all favorable for the normal activities of the animals used (Table 10 for tube 1) in this problem.

The following set of experimental conditions was maintained in tube 2 , which contained 250 beetles; however, in this case the soil was kept only slightly moist and the first $5 \mathrm{~cm}$. was used as a dry mulch, so that less moisture was lost through evaporation. The same food plants, Solanum hertwigii, were added 
thrice daily, but only a few small sprays were used each time, so that the air within the tube was free from dampness, a condition which would have increased the evaporation rate and assisted in making the environmental situation unfavorable. The envirommental conditions in this case were normal, in so far as the food-supply was a factor; but the other surroundings were modified, at least as to the high rate of evaporation (Table 10 for tube 2). Both tubes 1 and 2 were planned to give the ascertained differences in evaporation-rates; accordingly tube 1 produced a lower and tube 2 a higher rate, but the food relations for both were approximately normal.

No plants were used in tubes 3 and 4 , but each tube was wrapped with several thicknesses of coarse absorbent paper; at the beginning of the test the soil within each was saturated with water, but no water was added during the experiment. Around the outside of tube 4 was placed a coil of lead-tubing drilled full of holes, and this was connected to a carboy of water. This device kept the absorbent paper surrounding the tube saturated and, furthermore, a large piece of oil-cloth was wrapped to the height of $15 \mathrm{~cm}$. around the base of the tube and beneath the absorbent paper. This oil-cloth was extended out in all directions for about $60 \mathrm{~cm}$. from the bottom of the cage, so that the dripping water did not come in direct contact with the soil in the tube. On the other hand, no water was added to tube 3 , so that this cage was kept dry during the experiment. These conditions, therefore, produced a high rate of evaporation in tube 4 and a low one in tube 3 (Table 10). The results for each of these tests follow.

The 1,000 bectles used in this experiment were grown under the same environmental conditions and from the same parents, and, moreover, these animals had emerged as adults from the pupa state synchronously; so they were then as nearly uniform physiologically as it was possible to obtain them. The conclusions showed for tube 1 with plenty of food and moisture, when the individuals were counted at the end of the experiment, that there was no hibernation; 28 were found dead upon the soil. In tube 2 , with plenty of food, but in which the air was kept dry, the census, when taken at the end of the test, showed that $15 \%$ had successfully hibernated and that 93 had died. At the end of the experiment tube 3, which contained dry air and no food plants, showed 129 beetles in hibernation and 121 dead ones. Tube 4, which was supplied with moisture but with no food, at the end of the test gave no evidence of hibernation; 73 of the 250 beetles originally present were found dead upon the soil. These results proved that newly emerged adults of the fall generation can not be caused to hibernate under normal conditions, but that if the surrounding medium was dry a type of hibernation reaction did result through desiccation. Such deductions are possible, since the evaporation rates in Table 10 show that a low rate retarded hibernation and a high one accelerated this behavior.

It is also true that this entrance into hibernation may be of the normal type, which always occurs under normal conditions in the winter generation. Low temperature, however, was an important factor at Chicago, but this kind of hibernation also took place in the pure winter-generation stock, even under high temperatures. This behavior was further studied in the second generation of the year under the following set of experimental conditions.

At Tucson Station A this type of hibernation reaction in beetles of the winter generation (Tucson A, g. II) was observed to appear under a normal environmental complex in the fall of 1911, but all other hibernations (Tucson A, g. IV), 
which took place under adverse circumstances in the early fall of 1912, were of the induced type. At Tucson Station B this behavior was not discovered in either the winter generation of 1911 or that of 1912, since the environmental conditions always produced desiccation in the early fall at this locality, thus causing the beetles to be in hibernation about 10 months each year; they emerged about the middle of July, and after feeding for a short period re-entered hibernation late in August. At the Chicago Station, however, normal hibernation always occurred, because the environment was normal, for no excessive desiccation or any other climatic adversities appeared. It became necessary, therefore, to determine if these results could be confirmed by further data, so the following hibernation tests were carried out.

For these tests 30 emerging adults (Tucson A, g. II) on September 2 were placed in a hibernating pedigree-cage containing potato plants for food; the soil was a mixture of equal parts of sand and adobe, and water was added twice daily, but the plants completely filled the cage. The experimental conditions, therefore, were apparently normal throughout the test. It was discovered by daily observations that these animals were in hibernation on September 18 and when dug up on October 2, the first adults were uncovered at a depth of $20 \mathrm{~cm}$., but the larger number of beetles were found at the bottom of the pot. The beetles were inactive when first removed, but began to move in a few minutes at an air-temperature of $33^{\circ} \mathrm{C}$. Various tests in the field demonstrated that they possessed no reactions to food or dry soil, but within 5 minutes they did respond, and all burrowed into the moist earth at a temperature of $21^{\circ} \mathrm{C}$. This indicated that a cool moist soil accelerated the entrance reaction. These results were further tested to determine if similar reactions always took place.

On September 2, 130 emerging adults (Tucson A, g. II) were put into a hibernating cage, which had been previously filled with potato plants, and in which the soil consisted of a mixture of equal parts of adobe and sand, to which water was added twice daily; thus the conditions were approximately normal, for no desiccation occurred. The beetles responded to this set of conditions, for they were in hibernation by September 22. When dug up on October 21 the insects were found distributed through the soil from the top to the bottom of the cage, but when tested in the field showed no reaction to food or dry soil, and when brought into contact with cool moist soil, out-of-doors, they burrowed into it within 5 minutes.

This activity was again tested in the following manner: 51 emerging adults (Tucson A, g. II) were removed September 3 and were placed in a hibernating cage filled with Solanum hertwigii for food. In this experiment a different food plant was also used, but with no apparent result upon their behavior. The soil was also of equal parts of sand and adobe, and water was added each morning and evening, so that the experimental conditions were apparently normal. All the animals were in hibernation by September 19, but when dug up on October 3 only 46 adults were alive. The first individuals, however, were discovered at a depth of $29 \mathrm{~cm}$., and the majority were at the bottom of the pot. When tested in the field no reactions to food or dry soil were observed, but when brought into direct contact with cool moist earth all burrowed into it immediately. Thus when normally hibernating beetles of the winter generation were removed from hibernation a cool moist soil was necessary to initiate this behavior. 


\section{ACTIVITIES DURING HIBERNATION.}

It was observed that hibernating beetles were inactive when first dug from the soil, and if the insects were moved to a warm room they soon began to crawl; then entrance into hibernation occurred if they were brought into contact with moist earth. At Chicago, during the winter of 1911-12, it was observed that beetles which had hibermated out-of-doors migrated more deeply than usual during the cold winter. From the following test it appeared that beetles would move to moist regions in the earth during hibernation, for late in April 1912, at Tucson Station A, several hundred individuals were found to be hibernating in the open air cage. Accordingly a corner of this cage was watered and the soil was sifted; thus, all the beetles were removed in that locality, but the newly dug soil was kept moist, and each week it was examined for adults; during each observation a large number was always discovered.

\section{WATER RELATION OF SOILS AND HIBERNATING BEETLES.}

The beetles hibernate in small cavities or cells, which contain air of a relative humidity, that is in proportion to the water-content of the surrounding earth. During heary rains the soil becomes flooded with water, so that some air is dricen from the cavities, but if the rain continues for too long a period the beetles may die. On the other hand, if the soil is too dry, desiccation of the insects takes place and death may result; therefore, the part soil-moisture plays in mortality during hibernation is of great significance. Tower (1906), in discussing results with soils, states:

"The water-content of soil is controlled, not by an abundant rainfall, nor by telluric water, but almost wholly by adhesion and capillarity in the soil-that is, physical conditions alone, such as permeability, capillarity, and the power to absorb and to retain water are the factors which influence the moisture content of soil .... In all soils the pores which do not contain water are filled with air in which the percentage of relative humidity is controlled by the amount of water in neighboring pores. Likewise, the cells in which these beetles pupate are filled with air: the relative humidity is controlled by water in the pores of the surrounding earth."

Thus the physical composition of the soil is important in preserving insect life, and the adobe soil of the Tucson Desert, although it contains but little moisture, does possess other physical potentialities which act in retaining moisture, for through drying it becomes imperrious to water and hibernating animals are sealed up in their cells and thus preserved from desiccation. To determine how dry the adobe soil was when containing living beetles, samples of it were taken from the walls of the cells (Table 11) and those of June 30

TABLE 11.

\begin{tabular}{|c|c|c|c|c|c|}
\hline Date. & Depth. & Wet soil. & Dried soil. & Water-Іовв. & Water-content. \\
\hline $\begin{array}{l}\text { April } 1 \ldots \\
\text { April } 8 \ldots \\
\text { April } 30 . \\
\text { June } 30 .\end{array}$ & $\begin{array}{r}c m . \\
25 \\
25 \\
25 \\
5 \\
10 \\
20\end{array}$ & $\begin{array}{c}\text { oms. } \\
60.93 \\
122.22 \\
123.84 \\
58.94 \\
76.55 \\
58.09\end{array}$ & \begin{aligned} \multicolumn{1}{c}{$g m s} \\
56.18 \\
110.00 \\
115.89 \\
57.64 \\
73.55 \\
55.45\end{aligned}$. & $\begin{array}{c}\text { gms. } \mathrm{H}_{2} \mathrm{O} \text {. } \\
4.75 \\
12.22 \\
7.95 \\
1.30 \\
3.00 \\
2.54\end{array}$ & $\begin{array}{c}\text { percent } \mathrm{H}_{2} \mathrm{O} \text {. } \\
8.45 \\
11.11 \\
6.85 \\
2.25 \\
4.07 \\
4.45\end{array}$ \\
\hline
\end{tabular}


showed an average of less than 4 per cent water of their dry weights. This was during the dry season, when no beetles had emerged from hibernation up to the above date, but on July 1 , the day following, 0.98 inch of rain fell; 73 beetles emerged on July 2, and by July 3 eggs were laid. This sharp response in behavior must be attributed to the water-content of the soil, for the beetles emerged imimediately after the first rain and oviposition took place within 48 hours. The insects of the surrounding desert showed a similar response, inasmuch as the adobe soil held them imprisoned until the first rain, which raised their water-content and softened the soil so that emergence of immense numbers occurred.

The following experiment was performed to show the relation of physical composition of soils to mortality during hibernation. Three hibernating cages were prepared containing soils, one was composed of sand, another of adobe, and a third of equal parts of sand and adobe. On October 1, 500 hibernating adults were caused to hibernate artificially in each tube by placing the insects at a depth of $40 \mathrm{~cm}$. in the soil, and the soil within each tube was kept slightly moist until late in October; they were then allowed to remain out-of-doors under natural conditions during the winter until May 1, when water was added to each cage. On May 3, 362 adults emerged from the soil mixture, 251 from the adobe, but none from the sand. On May 5, the soil of each cage was sifted, when it was found that all in the pure sand were dead but that only 27 in the adobe and 23 in the soil mixture had succumbed. It appeared, then, that there was a relation between soil composition and mortality during hibernation, for the sand permitted excessive desiccation to oceur, the adobe and mixed soils did not admit of great desiccation, but most individuals were hibernated successfully in the mixture of equal parts of adobe and sand.

\section{EMERGENCE FROM HIBERNATION.}

The physiological complex of emerging beetles was next considered in reference to two phases of the problem. In one case the reactions of hibernating beetles caused to emerge by applying water to the soil were determined, and in the other the reactions of similar adults, in which emergence was produced by sifting the soil, were tested. In the first experiment hibernating beetles (Tucson A, g. II) were encouraged to emerge by applying water on June 1, when they were removed to the constant-temperature room; their reactions were found to be positive to light, but negative to gravity. The light response was further tested by placing 5 beetles in each of 10 test-tubes and each tube was placed so that one-half of it was in the shade of the laboratory roof and the other half in direct sunlight. The beetles all oriented and moved out into the sunlight at the end of each tube, where they remained, and in a few minutes were dead. The air-temperature in the exposed ends of the tubes was $5 \%^{\circ} \mathrm{C}$. In this experiment the organisms reacted to sunlight and the suggestion that possibly the red or blue rays might have influenced this result led to the next test.

Of 50 hibernating individuals (Tucson A, g. II) emerged after adding water on June 3,25 were put in each of two test-tubes; one of which was placed in direct sunlight under a red bell-jar containing a potassium-bichromate solution, and, while no deaths occurred, no definite reaction was observed; the other was placed in the direct sunlight beside the former, under a blue bell-jar provided with a solution of copper sulphate, when all became positive to the rays and 
none died. We may therefore conclude that death in the first experiment was due to heat.

Many tests of various kinds have been given elsewhere and with the same result-that when hibernating beetles were caused to emerge by applying water, they reacted positively to light and negatively to gravity. The next experiment consisted in testing the reactions of hibernating beetles, in which emergence was attained by digging and no water was added to the cage.

For this test 47 hibernating beetles (Tueson A, g. II) were removed by digging at $8 \mathrm{p} . \mathrm{m}$. on June 12 . They were negative to a $32 \mathrm{c} . \mathrm{p}$. lamp, but 23 of these insects were positive to candle-light of a weak intensity. These were immediately placed under a bell-jar containing moist filter paper, and when tested on June 13 they were found to be positive to light but negative to gravity. This behavior was repeated in the following case.

Twelve hibernating beetles (Tucson A, g. II), when removed by digging at 7 p. m. on June 20, were found to weigh 1.2573 grams, but they gave no response to light or gravity. (A soil-sample taken from the earth surrounding the beetles showed that it contained water to the extent of 12.7 per cent of dry weight.) When the animals were placed in a humidor at 10 a. m. on June 22, they weighed 1.3057 grams, having absorbed 0.1484 gram of water from the moist chamber; 10 of these beetles, when tested, were positive to light, but 2 , which were inactive, died in a very short time after the experiment. The 10 adults were also negative to gravity, for when placed in the constant-temperature darkroom, all crawled to the top of the cylindrical wire-netting tube. These experiments showed that positive phototropic and negative geotropic reactions were induced in hibernating beetles by increasing the water-content of the surrounding medium, because the beetles under the moist bell-jar increased in weight and imbibed water directly from the moist air. It was also true that they absorbed water from the air in the soil. This relation was further shown in the following observations, which were made upon the emergence response.

The time of emergence is controlled by the environmental complex, for if water were added to the medium surrounding hibernating beetles, when the soil temperatures were above $14^{\circ}$ to $16^{\circ} \mathrm{C}$., emergence resulted. This was evident at Tucson, for no emergence was discovered at either station until the rainy season in July, and furthermore, the winter rainy season caused no emergence because of low temperatures. At Chicago, emergence occurred whenever the soil-temperatures reached $14^{\circ}$ to $16^{\circ} \mathrm{C}$., for enough precipitation always took place during the winter and spring months so that emergence occurred as soon as the proper temperature relations existed, which was from May 20 to June 25.

\section{SUMMARY AND DISCUSSION UPON THE RELATION OF WATER TO HIBERNATION.}

The conclusions arrived at from these previous results indicated that a type of hibernation might be produced at any time through desiccation, except with low temperatures, when little desiccation took place. This condition produced a loss of water from the beetles in such a way that they responded negatively to light and positively to gravity, so that they burrowed into the soil and remained there until the moisture-content of the soil was sufficiently high. They then absorbed hydroscopic water, which raised their water-content and reversed their reactions, so that they became positive to light and negative to gravity, hence 
their emergence, so that now, in case other conditions were suitable, they were ready to enter upon their reproductive activities. Below $12^{\circ}$ to $15^{\circ} \mathrm{C}$. in soiltemperature the water-relation was not the controlling factor, but the duration of the hibernating period depended upon the length of the dry season in an arid complex and upon the length of winter (low temperature) in a temperate region.

Baumberger (1914) reviews, at length, the literature on hibernation of insects and reaches the following conclusions, chiefly from his own researches:

"1. That temperature is but a single factor and not necessarily the controlling one in hibernation.

" 2 . That hibernation is usually concomitant with overfeeding and may be the result of that condition or the result of accumulation of inactive substances in the cytoplasm of the cell due to feeding on innutritive food.

" 3 . That the loss of water which is general in hibernation probably results in a discharge of insoluable alveolar cytoplasmic structures which have accumulated and produced premature senility with an accompanying lowering the rate of metabolic processes.

"4. That starvation during hibernation, together with loss of water, may result in rejuvenation, when aided by histolysis, and an increase in permeability.

" 5 . That this rejuvenated condition and increased permeability will, if stimulated to activity by heat, permit pupation in codling-moth larvæ, which in this case is the termination of the hibernating conditions."

The results of Sanderson and Peairs (1913) add another condition for hibernation that was also discovered by Tower (1906) for the potato-beetle; this is the influence of heredity. The former authors reached the following conclusions:

"That our first work was an effort to show that emergence from hibernation was due to an accumulation of temperature, but it soon became apparent that hibernation is very largely controlled by the influence of heredity, and that the relation of the temperature and inheritance must be determined for each species."

For the Mexican cotton boll weevil, Hunter and Hinds (1904) found that dryness was more desirable for hibernation and that mortality during hibernation was greater from exposure to moisture than from cold; but, on the other land, high temperatures and moisture were the best conditions for the development of such beetle larvæ. In this connection, Baumberger (1914) stated:

"The effects of ether on plants is similar to hibernation and since the action of ether is probably a drying one, this may throw light on the importance of moisture in hibernation."

Loeb (1906) says:

"The lack of water acts similarly to a low temperature. This is the reason why seeds can be kept alive so long. Lack of water may reduce the reaction velocity of the hydrolytic processes in seeds at ordinary temperature so considerably that it may become practically zero."

The snail, according to the results of Kühn (1914) loses weight in winter and reacts to drought in summer. Unless it contains a large amount of water, no dry food is taken, and if placed under moist conditions when in hibernation it will come out of its closed shell. Bellion (1909) finds that a low moisturecontent of the air is the determining hibernating factor in the European snail, 
and Baker (1911) shows that snails during dry seasons form an epiphragm; they usually bury thenselves during hibernation and æstivation. On the other hand, Pearl (1901) finds that the terrestrial slug Agriolimax can hibernate in cold water.

In the vertebrates, Rulot (1901) determines for the bat that the proportion of water increases during hibernation from November to April; but there actually was a loss of water, more in proportion at the end than at the beginning. Polimanti (1904) finds that an increase in humidity increases the pounds in a marmot during hibernation.

In conclusion, the work of Sanderson (1908) agrees most closely with my results upon hibernation. In discussing the relation of temperature to the hibernation of insects, he states:

"In come cases, however, the time of emergence from hibernation is controlled by moisture conditions as well as temperature, or independent of temperature. Thus Tower kept the potato beetle in hibernation for 18 months at a high temperature but with a dry atmosphere, and they emerged as soon as normal moisture conditions were produced. Webster and Hopkins have shown a similar effect of the lack of rainfall on the emergence of the Hessian fly in the fall. In relation to hibernation in humid climates the matter of moisture is probably not a controlling factor, but undoubtedly has the most important influence upon the time of emergence of forms in æstivation during the summer or in an arid region."

My results upon the potato-beetle substantiate the work of Sanderson.

\section{EFFECT OF CHANGES IN WATER-CONTENT UPON ALTERATIONS IN TROPIC ACTIVITIES.}

The experiments and observations upon $L$. decemlineata proved that, when surrounded by a moist medium, the beetles were positive to light and negative to gravity. It is also evident from previous tests that if the moisture of the surrounding medium was decreased, desiccation resulted, so that the insects were reversed in their behavior and reacted negatively to light and positively to gravity. These beetles, however, responded to any intensity of light if moved from a lesser to a greater intensity, and accordingly when moved from darkness into the moonlight at Tueson they always reacted; and in many instances insects which were negative to a strong light were also positive to a weak one.

It was shown by Burdin (1913) that heat and dryness stimulate positive reactions in terrestrial amphipods, while cold, moisture, and quiet favor negative reactions. The results of Dice (1914) prove that light of high intensity makes daphnias positively geotropic, but a decrease in light intensity has the reverse effect; and furthermore, these animals tend to become positively geotropic in high temperatures and negatively geotropic in low. Kanda $(1916 a)$, in studying geotropism in a marine snail, found that it is negatively geotropic, but most individuals would orient positively if placed on a dry glass or wooden plate. Later, Kanda (1916b) demonstrates for fresh-water snails that they are negatively geotropic when their lungs are empty and positively geotropic when their lungs are full of air. Olmsted (1917) finds that food is a factor in the reversal of the behavior to gravity in Planaria maculata. Adams (1903) concludes that earthworms retreat into their burrows during the daytime because of their negative phototropism, but they emerge at night not so 
much because of darkness as because of their positive phototropism for faint light. Wilson (1891) shows that Hydra is negative to bright light and positive to dim light. According to McGinnis (1912), Branchipus serratus is positively geotropic in light and negatively geotropic in darkness; darkness rather than light may furnish the stimulus to this reversal. In studying the reactions of Drosophila to gravity, Cole (1917) finds that the response to gravity is much less marked in flying than in creeping, where it is very definite.

Many animals orient in the field in relation to the center of gravity of the earth. Loeb (1905) found that some animals turn their heads upward and others downward. To this latter class belongs the garden spider, which he found may hang in this position in the center of its web for hours. He discovered the same behavior in some diptera. Shelford (1917) states that such animals as the grasshopper usually orient with the head up, while aphids and katydids orient with the head down. In the potato beetle the majority of larvæ and a large number of adults orient with the dorsal side down.

There is a vast amount of literature dealing upon reversibility in phototropism through chemical agencies. Loeb (1893 and 1904) proves that it was possible to reverse the reactions of a large number of water forms through chemicals such as salts, acids, and the like. According to Moore (1912a, 1912b, and 1913), phototropism in Daphnia and Diaptomus may be influenced through the agency of caffein, strychnin, atropin, acids, alcohol, and ether. Moore (1913) says:

"While negative phototropism in Diaptomus can be reversed by acids, but positive phototropism brought about by chemical means can not be reversed by strychnin (atropin or caffein)."

Wolfgang (1912) determines that electrolites influence phototaxis, and Kanda (1914) reversed geotropism in Arenicola larvæ by means of salts.

\section{EXPERIMENTS UPON THE RÔLE OF WATER IN GEOTROPISM.}

On May 15, at 8 p. m., 21 freshly emerged beetles (Tucson A, g. I) were moved to a constant-temperature room and tested 10 times as to their reactions to gravity, and in each test all were negative. These geotropic reactions were tested in the dark, and if the beetles crawled to the top of the tube, when held in a vertical position, they were considered as positive and if they crawled to the bottom as negative. The thermograph tracings showed a constant temperature of $21^{\circ} \mathrm{C}$., with a daily variation of $1^{\circ} \mathrm{C}$., throughout the test. Again at 11 a. $\mathrm{m}$. on May 16, when tested as previously (10 times), they were still negative to gravity, and at this time weighed 2.0009 grams; furthermore, on May 17 at $10^{\mathrm{h}} 30^{\mathrm{m}}$ a. m., they weighed 1.9294 grams, and again gave the same test to gravity, so that these results proved that the beetles under these conditions were uniform for this reaction. For experimental purposes these insects were divided into three groups. The first group of 7 adults was put into a calcium-chloride chamber, which produced so high a rate of evaporation as to desiccate them; the second of 7 individuals was subjected to a low rate of evaporation by placing wet filter-paper under the bell-jar, so that little water was removed from them under these conditions; in the third chamber 7 adults 
were used as a control. In table 12 , the results are given, which shows that group 1 at the beginning of the test was negative, but by $9^{\mathrm{b}} 30^{\mathrm{m}}$ a. m., while under the dry bell-jar, all became positive, but when moist conditions were restored in the jar, by $10 \mathrm{a} . \mathrm{m}$. on May 26 , they were again negative. In group 2 , at the beginning, all were negative and remained thus as long as they were kept under moist conditions, but at $10 \mathrm{a} . \mathrm{m}$. on May 30, all had become positive. In

TABLE 12.-Reversal in the potato beetle to gravity.

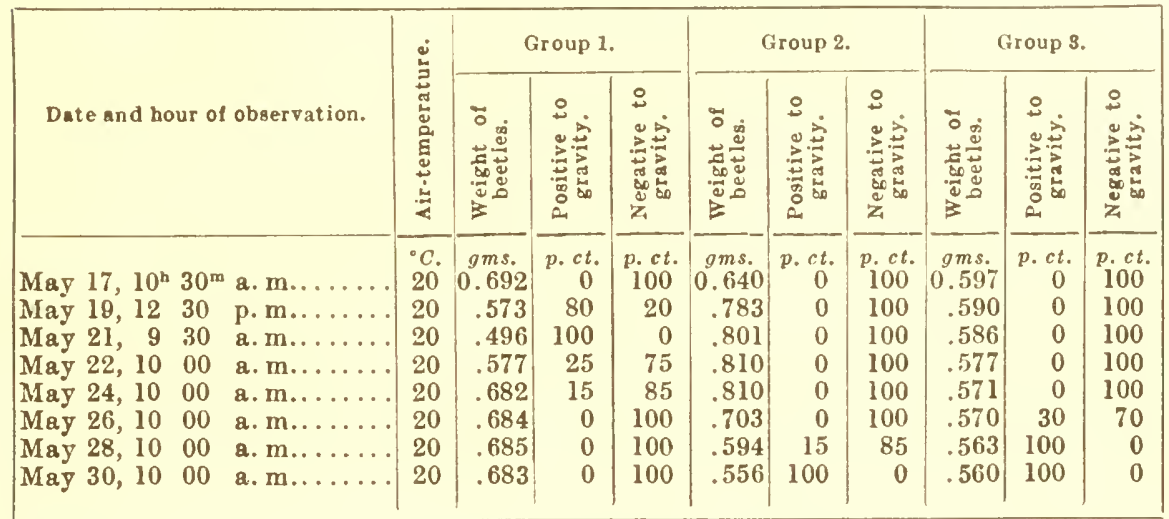

Note.-In group 1 the conditions in bell-jar were dry on May 17, 19, and 21, and moist on the other days. In group 2 said conditions were dry on May 26,28 , and 30 , and moist on other days. In group 3 said conditions were unlform throughout.

group 3, which were the control individuals, a gradual loss of weight occurred until $10 \mathrm{a}$. m. on May 28, when all were positive. These results showed clearly that reactions to gravity may be reversed through changes in the moisturecontent of the surrounding medium.

\section{RELATION OF TEMPERATURE TO THE OUTGO AND INTAKE OF WATER.}

An interesting discovery was the determination that there was little absorption of water below $12^{\circ} \mathrm{C}$. as was shown in a test in which beetles emerging from pupation were collected on July 28; they were placed under a bell-jar containing wet filter-paper, where they remain until 12 midnight on July 30 , when equal numbers of insects were placed in two bell-jars, in a refrigerator, at a temperature of $10^{\circ}$ to $13^{\circ} \mathrm{C}$. One bell-jar contained wet filter-paper and the other calcium chloride, but weighings made at frequent intervals showed that in the humidor there was no appreciable loss during the 84 hours in the refrigerator. In another test, desiccated beetles were placed under saturated bell-jars in the refrigerator, but weighings made at frequent intervals gave no evidence of water-absorption. These results showed how much organisms were protected from absorbing water during winter rains, which would otherwise result in their freezing, and further demonstrated that desiccation, occurring slowly at a low temperature, was a factor in the economy of the organism.

A similar result was obtained with upper temperature limits. It is known that the coagulation temperature of colloids varies with the amount of contained 
water, a condition with which our results on $L$. decemlineata agreed generally, since the death-point in potato beetles with a high water-content was $58^{\circ}$ to $60^{\circ} \mathrm{C}$., and desiccated ones withstood $1^{\circ}$ to ${ }^{\circ} 5$ higher temperature. Bachmetjew (1902) shows that the temperature of the insect's body varied with the conditions, namely, moisture, temperature, and the like. If the air was damp, the body-temperature was higher than that of the surrounding medium, since no evaporation occurred; but if the air was dry it cooled through evaporation. He also pointed out that the smaller the percentage of fluids in a unit of the living insect body, the lower was the normal congealing-point of the fluids. Tower (1906) states that soil-temperatures taken on the savannas of Vera Cruz in April 1904, in places where $L$. decemlineata was æstivating, were frequently as high as $60^{\circ}$ to $65^{\circ} \mathrm{C}$., and that success in passing through these high temperatures at the end of the dry season depended upon the completeness of the physiological changes preceding entrance into hibernation. These results were similar to those just given for this insect, which showed that the lower and upper temperature limits were influenced through water-relation.

In studying longevity in insects, Baumberger (1914) shows that the temperature at which colloidal substances coagulate lowers with a decrease in water-content and that long exposure to cold or high temperature may result in this decrease in water. He explains that the result of a long exposure to cold is the same as short exposure to heat, while intensity of cold shortens the length of the period. He also demonstrates that the point of coagulation varies with the water-content of the insects studied. Greely (1901) concludes that:

"A reduction of the temperature and a loss of the water have similar effects, because the cell loses water when the temperature is lowered, as well as when the concentration of the surrounding medium is raised."

The results of Livingston (1903) show for Spirogyra that a cell loses water when the temperature is lowered. In discussing the reversal in animal instincts, Loeb (1900) concludes that a decrease in temperature has the same physiological effects as a loss of water.

\section{METABOLISM AND THE WATER-REIATION.}

The results of various workers show that desiccation modifies the rate of metabolism; thus, the alterations in the behavior of the potato beetle may be due to differences in metabolic activity, brought about through combined relations of water and temperature of the organism. Shelford (1913) states that the changes in activity of the animals used in his experiments were due to the withdrawal of water.

It is known that anything which disturbs the rate of metabolism in an animal alters its response to a stimulus, and that reversed reactions in behavior are caused by changes in this metabolic process. According to Jennings (1904), Child (1910), Wodsedalek (1911), Allee (1912), Phipps (1915), and others a stimulus may change the physiological state of an animal, which produces a modified type of reaction. Many depressing agents are also known, such as potassium cyanide, chloretone, and a low oxygen content. Baumberger (1914) shows that starvation is an agent of this character, since it decreases metabolism by removing material to be oxidized. Loeb (1906), Mast (1911), Shelford (1914), and others further demonstrate that acids and alkalis increase irri- 
tability. The results of Shelford (1914) and of Chenoweth (191\%), however, agree most closely with those which are recorded in this paper. Both of these observers conclude that a high rate of evaporation increases sensibility or irritability through loss of water, a condition which might account for the alterations in the reactions of the potato beetle.

\section{GENERAL DISCUSSION UPON THE RÔLE OF WATER IN LIVING THINGS.}

In order to show why such a large number of reactions in the potato bectle were controlled by its water-relation, it was considered necessary to review only literature which bore directly upon these studies. "It was assuredly not chance," to quote Henderson (1913), "that led 'Thales to found philosophy and science with the assertion that water is the origin of all things." He also states that the action of water now appears to be a momentous factor in geological evolution, and the physiologist has found that water is invariably the principal constituent of living organisms. 'Thus, according to this observer, water makes up from 70 to 85 per cent of fishes, about 87 per cent of oysters, 85 per cent of apples, 78 per cent of potatoes, and 95 per cent of the edible portion of lettuce. It is interesting in this connection to add that my results upon the potato beetle show it to contain 80 per cent water. Henderson further says that the organism itself is essentially an aqueous solution in which are spread out colloidal substances of vast complexity, and as a result of these conditions there is hardly a physiological process in which water is not of fundamental importance. According to Livingston (1903), it is absolutely essential that every living mass of protoplasm be saturated with water, since vital phenomena occur solely in aqueous solutions.

Physiologists have long recognized that water is of the greatest importance for normal activity of tissues and that all exchanges of material, all supplies of food, and metabolic processes in general are dependent upon it. Aberhalden and Hall (1908) assert that water is absolutely necessary as a solvent for numerous compounds, for it brings into play various chemical reactions, which take part in building up and breaking down substances without number; it is also a carrier of nourishment to the borly and provides the means for the removal of its waste products. In discussing the physical importance of water, Hammarsten and Mendel (1911) show that water by its evaporation is an important regulator of temperature. Davenport (189\%) states that growth is due chiefly to imbibed water, and Estabrook (1910) also demonstrates that growth in paramocium is due almost solely to inhibition of water. MacDougal (1912), Jloyd (1905), and others demonstrated that many plants absorb water directly from the air. In respect to this subject, in animals the frog has perhaps received most attention, and according to Hill (1908) frogs take up water through the skin; they do not drink, for a thirsting frog with its gullet tied increases in weight no less than one with the gullet open. He also states that a frog can be gradually dried to less than 39 per cent of its normal weight without fatal results. Ny own data for the potato beetle show that it can be desiccated to less than 50 per cent and still live, while Catalpa lanigera will die if reduced by 25 per cent and the June bug if dried less than 15 per cent of its normal weight. 
It is not true that all animals do absorb water, for my experiments upon the scorpion and horned lizard (Phrynosoma cornutum) of the Tucson Desert indicated that these animals would not imbide any aerial water, and even when immersed in it no absorption was detected; furthermore, when desiccated no difference in weight was observed. A large scorpion lived for more than 2 months in a desiccator without food, but it probably died of starvation. If lizards do not absorb any appreciable amount of water or lose any through desiccation, then such a condition might demonstrate why they are distributed in a desert as well as in a hot humid region; therefore, the water-relation would not be the determining factor in a lizard's habitat, but the temperature-relation should be of greater importance in determining its distribution. This might also account for the results of Weese (1917), since he studied the reactions of the horned lizard to evaporation and temperature gradients, but found that the lizard responded definitely to temperature, while there was no marked reaction to evaporation. In this connection the work of Matthews (1913) is important. He says:

"There is a mechanism for rendering mammals tolerably independent of the moisture content of their environment, a mechanism most highly developed in the reptiles. A mechanism formed by the replacing of the wet skin of the amphibian by a dry or scaly skin; the perfecting of the kidneys to maintain osmotic pressure of the blood; the control of the sweat glands and loss of water by the intestines; the development of membranes non-permeable to salts so that añmals may sit in fresh water and Jose their salts. . . . By this improvement reptiles have secured almost complete independence of the water-content of their surroundings."

Water is essential to life, says Babcock (1912), for during the period of development it is the most abundant constituent of living organisms. He continues:

"Some of this water is imbibed directly, some of it is taken with solid food which is rarely dry, and some of it is formed within the organisms by metabolic changes in the organic constituents of the food and tissues, induced by respiration and other vital processes. The relative amount of water derived from each of these sources depends upon the kind of organisms, its period of growth, the nature of its food, its enviromment, and its activities."

His experiments show that many varieties of insects, such as the clothes-moth, the bee-moth, and the flour-beetle, the flour-moth, and others live during all stages of development upon foods containing less than 10 per cent of water. He concludes that nearly all the water used by insects feeding upon air-dried foods is metabolic. In my own experiments upon the potato-beetle and other animals there are no data upon metabolic water and its relation to behavior.

The results of Hegner (1916) further illustrate the water-relation in animals. He arranged an experiment npon oviposition in the potato-beetle, so that 35 batches of eggs were in the sunlight and 15 were in the shade. Those in the sun came to nothing, but all in the shade were hatched. It was found that development had started in the sunlight, but that desiccation probably arrested this process; therefore he concludes that the advantage of concealment is not so great as that secured by shielding the eggs from the desiccating properties of the sun. My results show that the majority of adults orient to gravity with their dorsal side down, which might explain why eggs are usually deposited on the under side of a potato-leaf. 


\section{SUMMARY AND CONCLUSION.}

In general the results indicate for the potato-beetle that:

(1) The optimum breeding activity of this insect coincides with the highest water-content of the atmosphere, since periods of oviposition are exactly concurrent with those of rain and low rates of evaporation.

(2) Differences in soil-moisture produce alterations in the water-content of these animals which modify their behavior, since beetles will lay their eggs sooner if they emerge from a soil of high moisture-content than if they issue from a dry soil.

(3) Egg-production is also modified by differences in the evaporating power of the air which surrounds these insects, since a low rate of evaporation encourages oviposition.

(4) The beetle dies if buried when all its activities are normal, but either the summer or winter generation may be buried without injury if previously desiccated.

(5) The adobe soil of the arid region retains a relatively high percentage of water and is thus an excellent medium for the sustentation of the life of this beetle, as in other desert animals.

(6) These insects exhibit a physiological behavior not unlike that of transpiration in plants; but further, their tropisms are modified by loss of water, which is governed by the evaporating power of the air.

(y) The evaporating power of the aif surrounding these insects determines their behavior through transpiration; even their responses to light and gravity are controlled by evaporation.

(8) Entrance into hibernation in a desert region may be produced at any time through desiccation, except at low temperatures, when little desiccation takes place.

(9) The hibernating period in an arid region is controlled by the duration of the dry season, but is dependent upon the length of the winter in a temperate region.

(10) The water-relation is the controlling factor in the emergence of this insect from hibernation if the temperature is above $15^{\circ} \mathrm{C}$.

(11) When surrounded by a moist medium (above $15^{\circ} \mathrm{C}$.), either atmosphere or soil, these beetles are positive to light and negative to gravity, but desiccation reverses this behavior.

(12) This insect absorbs very little water below $12^{\circ} \mathrm{C}$.; its death-point under a high water-content was found to be $58^{\circ}$ to $60^{\circ} \mathrm{C}$., but when desiccated it can withstand from $1^{\circ}$ to $5^{\circ} \mathrm{C}$. more of heat.

(13) Alterations in the behavior of the potato-beetle may be due to differences in metabolic activity as influenced through the water-relation.

(14) This animal also imbibed water directly, but no studies were made upon metabolic water.

We may conclude that Leptinotarsa decemlineata, when introduced from its grassland habitat into an arid region, is equilibrated immediately with respect to its surroundings, especially in regard to its water and temperature medium; that its behavior is changed to resemble those responses still present in an organism long accustomed to a desert complex, and that, since water is the 
limiting factor in an arid region and the prime essential for metabolism, the behavior of the potato beetle in a desert is determined chiefly by the watercontent of its environment. Henderson (1913) states:

"Water, of its very nature, as it occurs automatically in the process of cosnic evolution, is fit, with a fitness no less marvelous and varied than that fitness of the organism which has been won by the process of adaptation in the course of organic evolution.... In truth, Darwinian fitness is a perfectly reciprocal relationship. In the world of modern science a fit organism inhabits a fit environment."

These results upen the potato beetle indicate that its marvelous fitness and adaptation to water is such a "reciprocal relationship."

The experiments were performed at the Desert Laboratory of the Carnegie Institution of Washington, and it is a pleasure to acknowledge my indebtedness to its director, Dr. D. T. MacDougal, for his interest manifested. I must also acknowledge my great indebtedness to Professor W. L. Tower, of the University of Chicago, who made it possible for me to continue this problem at Tucson. The following bibliography gives only the literature cited.

\section{BIBLIOGRAPHY.}

ABERHALDEN and HALL. 1908. Text-book of physiological chemistry. Page 354.

ADAMS, G. P. 1903. On the negative and positive phototropism of the earthworm, Allolobophora fatida Say., as determined by light of different inten. sities. Amer. Jour. Physiol., vol. 9, pp. 26-34.

Allee, W. C. 1912. An experimental analysis of the relation between physiological states and reotaxis in Isopoda. Jour. Exper. Zoöl., vol. 13, pp. $269-344$.

BABCock, S. M. 1912. Metabolic water: Its production and rôle in vital phenomena. Univ. Wisc. Agr. Exp. Sta. Research Bull. No. 22, pp. 87-181.

Bacinietjew, P. 1902. Temperature of insects. American Nat., vol. 36, pp. 401405.

BAKER, F. C. 1911. The Lymnæidæ of North and Middle America. Chicago Academy of Science, Special Pub. No. 3.

Baumberger, J. P. 1914. Studies in the longevity of insects. Annals Entom. Soc. Amer., vol. 7, pp. 323-353.

Bellion, M. 1909. Recherche experimentale sur l'hibernation l'escargot. Ann. Univ. Lyon, ser. 27.

Breitenbeciler, J. K. 1911. The hibernation of a desert beetle (Leptinotarsa decemlineata Say). Year Book Carnegie Inst. Wash., No. 10, p. 55.

1912. The water-content and activity of animal organisms. Year Book Carnegie Inst. Wash., No. 11, pp. 71-72.

Brubin, M. T. 1913. Light reactions of terrestrial amphipods. Jour. Animal Behav., vol. 3, pp. 334-352.

Crinnowetir, H. E. 1917. The reactions of certain moist-forest mammals to air conditions and its bearing on mammalian distribution. Biol. Bull., vol. 32 , pp. 220-227.

ChILd, C. M. 1910. Analysis of form regulation with the aid of anesthetics. Biol. Bull., vol. 18, pp. 161-173.

CoLE, W. H. 1917. The reactions of Drosophila ampelophila Loew to gravity, centrifugation, and air-currents. Jour. Animal Behav., vol. 7, pp. 71-81.

Davenport, C. B. 1897. The rôle of water in growth. Proc. Bos. Soc. His., vol. 28.

DrCE, L. R. 1914. The factors determining the vertical movements of Daphnia. Jour. Animal Behav., vol. 4, pp. 229-265.

Estaввоoк, A. H. 1910. Effect of chemicals on growth in Paramocium. Jour. Exper. Zoöl., vol. 8, pp. 489-535.

Fuller, G. D. 1911. Evaporation and plant succession. Bot. Gaz., vol. 52, pp. 195208.

Greetry, A. W. 1901. An analogy between the effects of loss of water and lowering of temperature. Amer. Jour. Physiol., vol. 6, pp. 122-129. 
Hamilton, C. C. 1917. The reactions of some soil insects to evaporating power of air, carbon dioxide, and ammonia. Biol. Bull, vol. 32, pp. 159-182.

Hammarsten and Mandel. 1911. A text book of physiological chemistry. Page 21. HAwhins, L. A. 1910. The porous clay cup for the automatic watering of plants. Plant World, vol. 13, pp. 220-227.

HEgNer, R. W. 1916. The advantages chrysomelid beetles secure by concealing their eggs. Psyche, vol. 22, pp. 24-27.

Henderson, L. J. 1913. The fitness of the environment. The Macmillan Co., New York, 317 pps.

Hennings, C. 1907. Experimental-biologische Studien an Borken Käfern. I. Tomicus typographicus. Zeit. Land und Forst-wirt., T. 5, pp. 68-125.

HILL, LeONARD. 1906. Recent advances in physiology and biochemistry. London.

Hunter, W. D., and W. E. Hinds. 1904. The Mexican cotton boll weevil. U. S. Dept. Agr., Div. Entom., Bull. 45.

JAcons, M. H. 1909. Effects of desiccation on the rotifer. Jour. Exper. Zoöl., vol. 6, pp. 207-263.

JENNINGS, H. S. 1904. Physiological states as determining factors in the behavior of lower organisms. Carnegie Inst. Wash., Pub. 16, pp. 109-127.

KAMMERER, P. 1907. Vererbung erzwungener Fortpflanzungsanpassungen I und II, Mitteilung: Die Nachkommen der spätgeborenen Salamandra maculosa und der frühgeborenen Salamandra atra. Arch. f. Entwicklungsmech., 25.

KANDA, SAYKo. 1914. The reversibility of the geotropism of arenicola larvæ by Salts. Amer. Jour. Physiol., vol. 25, pp. 162-176.

- 1916a. Studies on the geotropism of the marine snail Littorina littorea. Biol. Bull., vol. 30 , pp. 57-84.

- 1916b. The geotropism of freshwater snails. Biol. Bull., vol. 30, pp. 85-97.

KürN, W. 1914. Beiträge zur Biologie der Weinbergschnecke (Helix pomatia L.). Zeit. Wiss, Zoöl., T. 109, pp. 128-184.

Livingston, B. E. 1905. The rôle of diffusion and osmotic pressure in plants. Univ. of Chicago Press, Chicago.

1906. The relation of desert plants to soil moisture and to evaporation. Carnegie Inst. Wash., Pub. No. 50.

1910. Relation of soil-moisture to desert vegetation. Bot. Gaz., vol. 50, pp. 241-256.

Lloy, F. E. 1905. The artificial induction of leaf formation in the ocotillo. Torreya, vol. 5, pp. $175-179$.

1912. The relation of transpiration and stomatal movements of the water content of the leaves in Fouquieria splendens. Plant World, vol. 15, pp. 1-15.

LoEB, JAcQues. 1893 . Ueber künstliche Unwandlung positiv heliotropischer Thiere in negativ heliotropischer und Umgekehrt. Pflügers Arch. f. d. ges. Pliysiol., T. 54, pp. 81-107.

1900. Comparative plysiology of the brain. New York.

1904. The control of heliotropic reactions in fresh-water crustaceans by chemicals, especially $\mathrm{CO}_{2}$. Univ. Cal. Pub. Physiol., vol. 2, pp. 1-3.

1905. Studies in general physiology, Part I. Univ. of Chicago Press, Chicago.

1906. Dynamics of living matter. Columbia Univ. Press, New York, pp. 233 .

MacDougal, D. T. 1912. The water balance of desert plants. Annals of Botany, vol. 26 , pp. 71-93.

MAST, SAMUEL O. 1911. Light and the behavior of organisms. John Wiley \& Sons, New York, pp. 410.

Matruews, A. P. 1913. Adaptation and the physiologist. Amer. Nat., vol. 47, pp. 90-105.

McGinnis, M. O. 1912. Reactions of Branchipus serratus to light, heat, and gravity. Jour. Exper. Zoöl., vol. 10, pp. 227-241.

Moone, A. B. 1912a. Concerning negative phototropism in Daphnia pulex. Jour. Exper. Zoöl., vol. 13, pp. 573-575.

1912b. Negative phototropism in Diaptomus by strychnin. Univ. Cal. Pub., Physiol., vol. 4, pp. 185-186.

1913. Negative phototropism of Diatomus through the agency of caffein, strychnin, and atropin. Science N. S., vol. 38, pp. 131-133.

Olmsted, J. M. D. 1917. Geotropism in Planaria maculata. Jour. Animal Behav., vol. 7 , pp. $81-87$.

Pearl, Raymond. 1901. A curious habit of the slug Agriolimax. Rep. Mich. Acad. Sci., 1901, pp. 75-76. 
Phipps, C. F. 1915. An experimental study of the behavior of amphipods with respect to light intensity, direction of rays, and metabolism. Biol. Bull., vol. 28, pp. 210-223.

Polimant, O. 1904. Sur les variations de poids des Marmottes en hibernation. Arch. ital. Biol., vol. 42, pp. 341-367.

Renner, O. 1910. Beiträge zur Physik der Transpiration. Flora, vol. 100, pp. 451-457.

- 1911: Experimentelle Beiträge zur Kenntnis der Wasserbewegung. Flora, vol. 103 , pp. 171-247.

Rulot, Hector. 1901. Notes sur l'hibernation des Chauves-souris. Arch. biol. Paris, T. 18, pp. 365-375.

SANDERson, E. D. 1908. The relation of temperature to the hibernation of insects. Jour. Econ. Entom., vol. 1, pp. 56-65.

Sanderson, E. D., and L. M. Peatrs. 1913. The relation of temperature to insect life. New Hamp. Coll. Agri. Exper. Sta. Tech. Bull. No. 7, pp. 1-125.

SEMPER, K. 1881. Animal life. New York.

Shelford, V. E. 1912. Ecological succession. IV. Vegetation and the control of land animal communities. Biol. Bull., vol. 23, pp. 59-99.

- 1913. The reactions of certain animals to gradients of evaporating power of air: A study in experimental ecology. Biol. Bull., vol. 25, pp. 84-120.

- 1914a. Modification of the behavior of land animals by contact with air of high evaporating power. Jour. Anim. Behavior, vol. 4, pp. 31-49.

- 1914b. The importance of the measure of evaporation in economic studies of insects. Jour. Econ. Entom., vol. 7, pp. 229-233.

- 1917. Suggestions as to field and laboratory instruction in the behavior and ecology of animals with description of equipment. School Sci. and Math., vol. 17, pp. 22.

Tower, W. L. 1906. An investigation of evolution in chrysomelid beetles of the genus Leptinotarsa. Carnegie Inst. Wash., Pub. No. 48.

WEESE, A. O. 1917. An experimental study of the reactions of the horned lizard, Pyrosoma modestum Gir. Biol. Bull., vol. 32, pp. 98-116.

Wilson, E. B. 1891. The heliotropism of Hydra. Amer. Nat., vol. 25, pp. 413-433.

WodsedAlek, J. E. 1911. Phototactic reactions and their reversal in the May-fly nymphs, H. interpunctata (Say). Biol. Bull., vol. 21, pp. 265-272.

Wolfgang, Ewatd F. 1912. On artificial modification of light reactions and the influence of electrolites on phototaxis. Jour. Exper. Zoöl., vol. 13, pp. 591-612. 
.

. 
LIBRARY OF CONGRESS

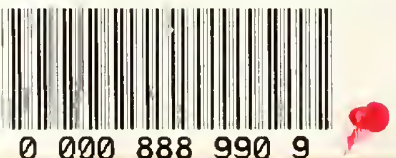

$\begin{array}{llll}0 & 000 & 888 & 990 \quad 9\end{array}$ 